\title{
Prediction of the neuropeptidomes of members of the Astacidea (Crustacea, Decapoda) using publicly accessible transcriptome shotgun assembly (TSA) sequence data
}

\author{
Andrew E. Christie* and Megan Chi \\ Békésy Laboratory of Neurobiology, Pacific Biosciences Research Center, University of Hawaii \\ at Manoa, 1993 East-West Road, Honolulu, HI 96822 USA \\ *Correspondence to: Dr. Andrew E. Christie, Békésy Laboratory of Neurobiology, Pacific \\ Biosciences Research Center, University of Hawaii at Manoa, 1993 East-West Road, Honolulu, \\ HI 96822 USA. Phone: 808-956-5212; FAX: 808-956-6984; Email: crabman@ pbrc.hawaii.edu
}

Key words: bioinformatics; neurohormone; neuropeptide; transcriptome shotgun assembly; crayfish 


\section{Abstract}

The decapod infraorder Astacidea is comprised of clawed lobsters and freshwater

22 crayfish. Due to their economic importance and their use as models for investigating

23 neurochemical signaling, much work as focused on elucidating their neurochemistry, particularly

24 their peptidergic systems. Interestingly, no astacidean has been the subject of large-scale

25 peptidomic analysis via in silico transcriptome mining, this despite growing transcriptomic

26 resources for this taxon. Here, the publicly accessible astacidean transcriptome shotgun

27 assembly data were mined for putative peptide-encoding transcripts; these sequences were used

28 to predict the structures of mature neuropeptides. One hundred seventy-six distinct peptides

29 were predicted for Procambarus clarkii, including isoforms of adipokinetic hormone-corazonin-

30 like peptide (ACP), allatostatin A (AST-A), allatostatin B, allatostatin C (AST-C) bursicon $\alpha$,

31 bursicon $\beta$, CCHamide, crustacean hyperglycemic hormone (CHH)/ion transport peptide (ITP),

32 diuretic hormone 31 (DH31), eclosion hormone (EH), FMRFamide-like peptide, GSEFLamide,

33 intocin, leucokinin, neuroparsin, neuropeptide F, pigment dispersing hormone, pyrokinin,

34 RYamide, short neuropeptide F (sNPF), SIFamide, sulfakinin and tachykinin-related peptide

35 (TRP). Forty-six distinct peptides, including isoforms of AST-A, AST-C, bursicon $\alpha$,

36 CCHamide, CHH/ITP, DH31, EH, intocin, myosuppressin, neuroparsin, red pigment

37 concentrating hormone, sNPF and TRP, were predicted for Pontastacus leptodactylus, with a

38 bursicon $\beta$ and a neuroparsin predicted for Cherax quadricarinatus. The identification of ACP is

39 the first from a decapod, while the predictions of CCHamide, EH, GSEFLamide, intocin,

40 neuroparsin and RYamide are firsts for the Astacidea. Collectively, these data greatly expand

41 the catalog of known astacidean neuropeptides and provide a foundation for functional studies of

42 peptidergic signaling in members of this decapod infraorder. 


\section{1. Introduction}

Among the most iconic infraorders of decapod crustaceans is the Astacidea, a taxon that

46 is comprised of clawed marine lobsters and freshwater crayfish. Five superfamilies are generally

47 recognized within the Astacidea (e.g. Bracken-Grissom et al., 2014), including four currently

48 extant ones: the Nephropoidea (homarid lobsters), the Enoplometopoidea (reef lobsters), the

49 Astacoidea (Northern Hemisphere freshwater crayfish) and the Parastacoidea (Southern

50 Hemisphere freshwater crayfish). At present approximately 800 living species are recognized

51 within the Astacidea, with the majority contained within the Astacoidea and Parastacoidea (e.g.

52 Crandall and Buhay, 2008). In fact, one family within the Astacoidea, i.e. the Cambaridae,

53 accounts for approximately half of all living astacideans (e.g. Crandall and Buhay, 2008).

The iconic nature of the Astacidea is due largely to the fact that many members of this

55 infraorder are highly prized and commercially important food species. For example, the

56 American lobster Homarus americanus represents a multimillion-dollar per year fishery in New

57 England and Atlantic Canada (the value of the 2013 landing for Maine alone was estimated at

58 \$364.5 million; http://bangordailynews.com/2014/02/28/news/state/maine-lobster-landings-

59 value-jumped-23-million-in-2013/), while extensive aquaculture initiatives are ongoing for many

60 freshwater crayfish species (e.g. Hunter, 1994). Members of the Astacidea are also of global

61 significance as invasive species (e.g. the environmental adaptability and fecundity of the

62 freshwater crayfish Procambarus clarkii has allowed it to colonize large portions of North

63 America, South America, Europe, Asia, and Africa, often at the expense of native aquatic species

64 [e.g. Barbaresi et al., 2004; Klose and Cooper, 2013; Matsuzaki et al., 2009; Yue et al., 2010]).

65 Many astacideans are also commonly used laboratory animals, both for educational exercises 
(e.g. Baierlein et al., 2011; Cooper et al., 2011; Leksrisawat et al., 2010; Robinson et al., 2011)

67 and for biomedical studies of neural network organization and neuromodulation (e.g. the stomatogastric and cardiac neuromuscular systems of lobsters and crayfish are among the

69 premiere models for studying the basic principles that underlie the generation, maintenance and modulation of rhythmically active motor behaviors [e.g. Fénelon et al., 2003; Hooper and

71 DiCaprio, 2004; Marder and Bucher, 2007; Selverston, 2005; Skiebe, 2001]).

Given their economic and biomedical importance, particularly their importance as models

73 for understanding neuromodulatory control, members of the Astacidea have been the subjects of

74 significant peptidomic analyses, particularly via mass spectral means (e.g. Bulau et al., 2004;

75 Cape et al., 2008; Chen et al., 2010; Christie et al., 2006, 2008a; Dickinson et al., 2007; 2008,

76 2009a, 2009b; Fu et al., 2005a; Jia et al., 2014; Jiang et al., 2012; Li et al., 2002; Ma et al., 2008,

77 2009a; Skiebe et al., 2002, 2003; Stemmler et al., 2005, 2006, 2007a, 2010; Yasuda et al., 2004;

78 Yasuda-Kamatani and Yasuda, 2004). Interestingly, and despite growing transcriptomic

79 resources for members of this decapod group (e.g. Glazer et al., 2013; Manfrin et al., 2013, 2015;

80 Stepanyan et al., 2006; Tom et al., 2013, 2014; Towle and Smith, 2006), only small-scale in

81 silico transcriptome mining for peptide precursors has been conducted for members of the

82 Astacidea (e.g. Christie et al., 2008b, 2010; Dickinson et al., 2007, 2008, 2009; Stevens et al.,

83 2009). Here, we have conducted an infraorder-wide, large-scale peptidomic investigation of the

84 Astacidea, mining the publicly accessible transcriptome shotgun assembly (TSA) data for

85 putative peptide-encoding transcripts and predicting peptidomes for three astacidean species $(P$.

86 clarkii, Pontastacus leptodactylus, Cherax quadricarinatus) using this sequence information.

87 The structures of 176 distinct peptides were predicted for $P$. clarkii, including members of the

88 adipokinetic hormone-corazonin-like peptide (ACP), allatostatin A (AST-A), allatostatin B 
89 (AST-B), allatostatin C (AST-C) bursicon $\alpha$, bursicon $\beta$, CCHamide, crustacean hyperglycemic

90 hormone $(\mathrm{CHH}) /$ ion transport peptide (ITP), diuretic hormone 31 (DH31), eclosion hormone

91 (EH), FMRFamide-like peptide (FLP), GSEFLamide, intocin, leucokinin, neuroparsin,

92 neuropeptide $\mathrm{F}(\mathrm{NPF})$, pigment dispersing hormone (PDH), pyrokinin, RYamide, short

93 neuropeptide F (sNPF), SIFamide, sulfakinin and tachykinin-related peptide (TRP) families,

94 while 46 distinct, mature peptides, including isoforms of AST-A, AST-C, bursicon $\alpha$,

95 CCHamide, CHH/ITP, DH31, EH, intocin, myosuppressin, neuroparsin, red pigment

96 concentrating hormone (RPCH), sNPF and TRP, were predicted for P. leptodactylus. An

97 isoform of bursicon $\beta$ and an isoform of neuroparsin were predicted for $C$. quadricarinatus. The

98 identification of ACP from P. clarkii is the first detection of a member of this peptide group in

99 any Decapoda, while the identifications of CCHamide, EH, GSEFLamide, intocin, neuroparsin

100 and RYamide are the firsts for the Astacidea. Taken collectively, the data presented here both

101 greatly expand the number of known astacidean peptides and provide a foundation from future in

102 silico and functional studies of peptidergic signaling in members of this important crustacean

103 taxon.

104

105 2. Materials and methods

106 2.1. Database searches

107 Database searches were conducted on or before January 10, 2015, using methods

108 modified from a well-vetted protocol (e.g. Christie, 2008a, 2008b, 2014a, 2014b, 2014c, 2014d,

109 2014e, 2014f, 2015a, 2015b; Christie and Chi, 2015; Christie et al., 2008b, 2010a, 2011a, 2011b;

110 Gard et al., 2009; Ma et al., 2009b, 2010). Specifically, the database of the online program

111 tblastn (National Center for Biotechnology Information, Bethesda, MD; 
112 http://blast.ncbi.nlm.nih.gov/Blast.cgi) was set to "Transcriptome Shotgun Assembly (TSA)" and

113 restricted to data from the Astacidea "(taxid:6712)". Known crustacean peptide precursors were

114 input into tblastn as the query sequences, and all hits returned by a given search were fully

115 translated using the "Translate" tool of ExPASy (http://web.expasy.org/translate/) and then

116 checked manually for homology to the target query. The complete list of peptide families

117 searched for in this study, as well as the specific queries used, is provided in Table 1; this table

118 also provides the BLAST-generated maximum score and E-value for each of the transcripts

119 identified as encoding a putative neuropeptide precursor.

120

121 2.2. Peptide prediction

122 The structures of mature peptides were predicted using a well-established workflow $(e . g$.

123 Christie, 2008a, 2008b, 2014a, 2014b, 2014c, 2014d, 2014e, 2014f, 2015a, 2015b; Christie and

124 Chi, 2015; Christie et al., 2008b, 2010a, 2011a, 2011b, 2011c, 2013; Gard et al., 2009; Ma et al.,

$1252009 b, 2010)$. Specifically, each of the deduced precursor proteins was assessed for the presence

126 of a signal peptide using the online program SignalP 4.1

127 (http://www.cbs.dtu.dk/services/SignalP/; Petersen et al., 2011); the D-cutoff values for the

128 program were set to "Sensitive". Prohormone cleavage sites were identified based on the

129 information presented in Veenstra (2000) and/or by homology to known arthropod

130 pre/preprohormone processing schemes. When present, prediction of the sulfation state of

131 tyrosine residues was conducted using the online program "Sulfinator"

132 (http://www.expasy.org/tools/sulfinator/; Monigatti et al., 2002). Disulfide bonding between

133 cysteine residues was predicted by homology to known peptide isoforms and/or by using the

134 online program "DiANNA" (http://clavius.bc.edu/ clotelab/DiANNA/; Ferrè and Clote, 2005). 
135 Other post-translational modifications, e.g. cyclization of amino (N)-terminal glutamine/glutamic

136 acid residues and carboxyl (C)-terminal amidation at glycine residues, were predicted by

137 homology to known arthropod peptide isoforms. Figure 1 shows three examples of mature

138 peptide structural prediction using the workflow just described; the mature structures of all

139 peptides predicted in this study are provided in Tables 2-4. All protein/peptide alignments were

140 done using the online program MAFFT version 7 (http://mafft.cbrc.jp/alignment/software/;

141 Katoh and Standley, 2013).

\section{3. Results}

144 In this study, 36 distinct peptide families/subfamilies were searched for within the extant 145 astacidean TSA sequence database (Table 1). In the interest of space, only those searches that 146 resulted in the identification of putative precursor-encoding transcripts are described here (Table 147 1), with the data presented in alphabetical order based on family name. All precursor proteins 148 listed as "full-length" exhibit a functional signal sequence (including a "start" methionine) and 149 are flanked on their C-terminus end by a stop codon. Proteins described here as "partial" lacked 150 a start methionine (referred to as C-terminal partial proteins), a stop codon (referred to as $\mathrm{N}$ 151 terminal partial proteins), or both of these features (referred to as internal protein fragments).

\subsection{Adipokinetic hormone-corazonin-like peptide}

154 A single $P$. clarkii transcript was identified as encoding a putative ACP precursor via a 155 tblastn search of the extant astacidean TSA database using a partial ACP preprohormone from 156 the remipede Speleonectes cf. tulumensis (Christie, 2014a) as the query sequence (Table 1). 157 Translation of this transcript revealed a 100 amino acid full-length precursor protein (Procl- 
158 prepro-ACP; Fig. 1A). Four peptides were predicted from Procl-prepro-ACP (Table 2 and Fig.

159 1A), one of which, pQITFSRSWVPQamide, possesses structural similarity to previously

160 described members of the ACP family (e.g. Hansen et al., 2010).

161

162 3.2. Allatostatin A

163 Two transcripts, one from P. clarkii and the other from P. leptodactylus, were identified

164 as encoding putative AST-A precursors using the sequence of a known P. clarkii prepro-AST-A

165 (Accession No. BAE45266; Yasuda-Kamatani and Yasuda, 2006) as the input query (Table 1).

166 Translation of the $P$. clarkii transcript revealed a 523 amino acid full-length prepro-hormone

167 (Procl-prepro-AST-A; Fig. 2A). Alignment of Procl-prepro-AST-A and $\underline{\text { BAE45266 }}$ is shown in

168 Figure 3A. As can be seen from this figure, with the exception of a 23 amino acid insertion in

169 BAE45266, the two proteins are essentially identical in sequence (one conservative amino acid

170 substitution), and thus may represent splice variants of the same gene. Thirty-six peptides were

171 predicted from Procl-prepro-AST-A (Table 2 and Fig 2A), 27 of which possess the C-terminal

172 motif-YXFGLamide, where $X$ represents a variable residue, which is the hallmark of the AST-A

173 family (Christie et al., 2010c). Of the AST-As, 24 are present as single copies within Procl-

174 prepro-AST-A, with three copies of one isoform, SGPYAFGLamide, present in the precursor

175 protein (Table 2 and Fig 2A). The nine linker/precursor-related peptides predicted from Procl-

176 prepro-AST-A are all distinct in structure (Table 2 and Fig 2A).

177 Translation of the $P$. leptodactylus transcript revealed it to encode a 93 amino acid

178 internal fragment of a precursor protein (Ponle-prepro-AST-A; Fig. 4A). Five peptides, three

179 distinct isoforms of AST-A (two full-length and one partial) and two distinct linker/precursor-

180 related peptides, were predicted from Ponle-prepro-AST-A (Table 3 and Fig. 4A). 
A single $P$. clarkii transcript was identified as encoding a putative AST-B precursor using

184 the sequence of Litopenaeus vannamei prepro-AST-B (Christie, 2014f) as an input query (Table

185 1). Translation of this transcript revealed a 92 amino acid N-terminal partial protein (Procl-

186 prepro-AST-B; Fig. 2B). Five distinct peptides were predicted from the extant portion of Procl-

187 prepro-AST-B (Table 2 and Fig. 2B), two of which, VGWSSMHGTWamide and

188 TNWNKFHGSWamide, possess the $-\mathrm{W} X_{6}$ Wamide C-terminal motif that is the hallmark of the

189 AST-B family (Christie et al., 2010c).

\subsection{Allatostatin $C$}

Two transcripts, one from $P$. clarkii and the other from $P$. leptodactylus, were identified

193 as encoding putative AST-C precursors using the sequence of a prepro-AST-C from the lobster

194 H. americanus (Dickinson et al, 2009b) as the input query (Table 1). Translation of the $P$.

195 clarkii transcript revealed a 164 amino acid full-length preprohormone (Procl-prepro-AST-C;

196 Fig. 2C). Four distinct peptides were predicted from Procl-prepro-AST-C (Table 2 and Fig. 2C),

197 one of which, GNGDGRLYWRCYFNAVSCF (disulfide bridging predicted between the two

198 cysteine residues), possesses structural features consistent with its inclusion in the AST-C

199 family, i.e. an unamidated C-terminus similar to the standard -PISCF motif and a disulfide

200 bridge between the cysteine residues located at positions 2 and 9 from the C-terminus (Christie et 201 al., 2010c).

202 Translation of the P. leptodactylus transcript revealed a 72 amino acid C-terminal partial 203 protein (Ponle-prepro-AST-C; Fig. 4B). Two peptides, SYWKQCAFNAVSCFamide (disulfide 
204 bridging between the two cysteine residues) and a partial linker/precursor-related sequence, were

205 predicted from the extant portion of Ponle-prepro-AST-C (Table 3 and Fig. 4C);

206 SYWKQCAFNAVSCFamide is the same AST-C variant derived from the H. americanus

207 prepro-AST-C used as the initial input query (Dickinson et al, 2009b).

208

209 3.5. Bursicon $\alpha$

210 Two transcripts, one from P. clarkii and the other from $P$. leptodactylus, were identified

211 as encoding putative bursicon $\alpha$ precursors using the sequence of Homarus gammarus pre-

212 bursicon $\alpha$ (Accession No. $\underline{\text { ADI86242; }}$; Sharp et al., 2010) as the input query (Table 1).

213 Translation of this transcript revealed a 142 amino acid full-length prehormone (Procl-pre-

214 bursicon $\alpha$; Fig. 2D). The bursicon $\alpha$ derived from Procl-pre-bursicon $\alpha$ is 121 amino acids in

215 length and is predicted by DiANNA analysis to possess disulfide bridges between its first and

216 third, second and sixth, fourth and ninth, seventh and tenth, and eighth and eleventh cysteine

217 residues (Table 2 and Fig. 2D); this $P$. clarkii peptide differs from that predicted from the $H$.

218 gammarus query at just eight residues, all but one of which is a conservative amino acid

219 substitution (alignment not shown).

220 Translation of the P. leptodactylus transcript revealed a 41 amino acid N-terminal partial

221 protein (Ponle-pre-bursicon $\alpha$; Fig. 4C). While very little of this putative precursor protein is

222 extant, the sequence that can be predicted differs at just three residues from the corresponding

223 portion of the $P$. clarkii protein described above, all in the putative signal peptide (alignment not

224 shown); the predicted partial P. leptodactylus bursicon $\alpha$ (Table 3 and Fig. 4C) is identical in

225 amino acid sequence to its $P$. clarkii counterpart (alignment not shown). 
Two transcripts, one from P. clarkii and the other from C. quadricarinatus, were

229 identified as encoding putative bursicon $\beta$ precursors using the sequence of a pre-bursicon $\beta$

230 from $H$. americanus (Christie et al., 2010a) as the input query (Table 1). Translation of the $P$.

231 clarkii transcript revealed an 89 amino acid C-terminal partial protein (Procl-pre-bursicon $\beta$; Fig.

232 2E). This partial peptide, likely the C-terminal portion of an isoform of bursicon $\beta$, differs at just

233 seven positions from the corresponding portion of the bursicon $\beta$ predicted from the $H$.

234 americanus query protein (alignment not shown); four of the seven variable residues are

235 conservative substitutions (alignment not shown).

236 Translation of the C. quadricarinatus transcript revealed a 48 amino acid C-terminal

237 partial protein (Chequ-pre-bursicon $\beta$; Fig. 5A). This partial peptide (Table 4 and Fig. 5A), the

238 C-terminal portion of a putative bursicon $\beta$ peptide, differs at 8 positions (all conservative amino

239 acid substitutions) from the corresponding portion of its $H$. americanus counterpart (alignment

240 not shown).

\section{3.7. CCHamide}

243 Three transcripts, two from P. clarkii and one from P. leptodactylus, were identified as

244 encoding putative CCHamide precursors using the sequence of L. vannamei prepro-CCHamide

245 (Christie, 2014f) as the input query (Table 1). Translation of one of $P$. clarkii transcripts

246 revealed a 118 amino acid full-length preprohormone (Procl-prepro-CCHamide I; Fig. 1B),

247 while translation of the other sequence revealed a 204 amino acid C-terminal partial protein

248 (Procl-prepro-CCHamide II; Fig. 2F). Four distinct peptides were predicted from Procl-prepro-

249 CCHamide I (Table 2 and Fig. 1B), one of which, SCSQFGHSCFGAHamide (a disulfide bridge 
250 between the position 2 and 9 cysteines), possesses the structural motif

$251 X \mathrm{CXXW} / \mathrm{Y} / \mathrm{FG} X X \mathrm{C} X \mathrm{G} X \mathrm{Hamide}$ (disulfide bridging between the position 2 and 9 cysteine

252 residues), which is the hallmark of members of the CCHamide family (Hansen et al., 2011).

253 Five distinct peptides, all different from those derived from Procl-prepro-CCHamide I, were

254 predicted from Procl-prepro-CCHamide II (Table 2 and Fig. 2F), including the partial peptide

255 +GGCLNYGHSCLGAHamide, which appears to be the C-terminus of an N-terminally extended

256 CCHamide (see below).

257 Translation of the P. leptodactylus transcript revealed a 246 amino acid full-length

258 preprohormone (Ponle-prepro-CCHamide; Fig. 4D). This precursor protein is very similar to the

259 extant portion of Procl-prepro-CCHamide II (i.e. 70.1\% identical/87.7\% similar in amino acid

260 composition over the extant portion of the $P$. clarkii protein; alignment not shown), and it is

261 likely to be the P. leptodactylus homolog of this precursor. Seven peptides were predicted from

262 Ponle-prepro-CCHamide (Table 3 and Fig. 4D), including

263 HRVMKGGCLNYGHSCLGAHamide (disulfide bridging between the position 8 and 15

264 cysteines), which appears to be an N-terminally extended isoform of CCHamide; the partial

265 CCHamide predicted from Procl-prepro-CCHamide II is identical in sequence to the sixth

266 through nineteenth residues of HRVMKGGCLNYGHSCLGAHamide, and may well be identical

267 to this CCHamide isoform.

269 3.8. Crustacean hyperglycemic hormone ( $\mathrm{CHH}) /$ ion transport peptide

270 Six transcripts, three from P. clarkii and three from P. leptodactylus, were identified as

271 encoding putative $\mathrm{CHH} / \mathrm{ITP}$ precursors using the sequence of $H$. americanus $\mathrm{CHH}$ A (Accession

272 No. P19806; de Kleijn et al. 1995) as the input query. Translation of the three P. clarkii 
273 transcripts revealed one sequence to encode an 85 amino acid internal protein fragment (Procl-

274 prepro-CHH I; Fig. 2G1), and the other two to encode 139 (Procl-prepro-CHH II; Fig. 2G2) and

275120 (Procl-prepro-CHH III; Fig. 2G3) amino acid full-length proteins. Each of the three $P$.

276 clarkii $\mathrm{CHH}$ precursors is predicted to give rise to one isoform of $\mathrm{CHH}$ (a partial peptide from

277 Procl-prepro-CHH I) and one linker/precursor-related peptide (Table 2 and Fig. 2G). Analysis of

278 the $\mathrm{CHH}$ predicted from Procl-prepro-CHH II by DiANNA suggests disulfide bridging between

279 the first and fifth, second and fourth, and third and sixth cysteine residues in this peptide (Table

280 2), a pattern of disulfide bonding stereotypical of members of the CHH superfamily (Böcking et

281 al., 2002). Analysis of the CHH predicted from Procl-prepro-CHH III by DiANNA, which

282 possesses only five cysteines, suggests disulfide bridges between the first and third and second

283 and fifth cysteine residues in the peptide (Table 2).

284 Translation of the three P. leptodactylus transcripts revealed two to encode full-length

285 precursor proteins of 137 (Ponle-prepro-CHH I; Fig. 4E1) and 140 (Ponle-prepro-CHH III; Fig.

286 4E3) amino acids, respectively, and the third, a 76 amino acid internal protein fragment (Ponle-

287 prepro-CHH II; Fig. 4E2). Each of the full-length proteins contains a single isoform of $\mathrm{CHH}$ and

288 one (Ponle-prepro-CHH I) or two (Ponle-prepro-CHH III) linker/precursor-related peptides; the

289 extant portion of Ponle-prepro-CHH II contains just a CHH (Table 3 and Fig. 4E). All of the $P$.

290 leptodactylus $\mathrm{CHH}$ and linker/precursor related peptides possess distinct structures (Table 3 and

291 Fig. 4E). Analysis by DiANNA of the three predicted P. leptodactylus CHHs suggests each

292 peptide possesses the stereotypical first and fifth, second and fourth, and third and sixth pattern

293 of disulfide bonding (Table 3).

294

295 3.9. Diuretic hormone 31 
Two transcripts, one from P. clarkii and the other from P. leptodactylus, were identified

297 as encoding putative DH31 precursors using the sequence of $H$. americanus prepro-calcitonin-

298 like diuretic hormone (Accession No. $\underline{\text { ACX46386}}$; Christie et al. 2010b) as the input query

299 (Table 1); calcitonin-like diuretic hormone is a synonym for DH31. Translation of the P. clarkii

300 transcript revealed a 136 amino acid full-length preprohormone (Procl-prepro-DH31; Fig. 2H).

301 Five distinct peptides were predicted from Procl-prepro-DH31, including

302 GLDLGLGRGYSGSQAAKHLMGLAAANFAGGPamide, a peptide possessing the structural

303 hallmarks of the DH31 family (i.e. an overall length of 31 amino acids, an amidated C-terminus,

304 and 13 highly conserved residues, $X X \mathrm{D} X \mathrm{GL} X \mathrm{RG} X \mathrm{SG} X X X \mathrm{AKX} X X X X X X \mathrm{AN} X X X \mathrm{GPamide}$

305 [Christie et al., 2010c]).

306 Translation of the P. leptodactylus transcript revealed a 66 amino acid C-terminal partial 307 protein (Ponle-prepro-DH31; Fig. 4F). Two peptides were predicted from the extant portion of 308 Ponle-prepro-DH31 (Table 3 and Fig. 4F), a linker/precursor-related peptide and the DH31 309 isoform GLDLGLGRGFSGSQAAKHLMGLAAANYAGGPamide.

\section{3.10. Eclosion hormone}

312 Two transcripts, one from P. clarkii and the other from P. leptodactylus, were identified 313 as encoding putative EH precursors using the sequence of Daphnia pulex pre-EH (Dircksen et al. 314 2011) as the input query (Table 1). Translation of the P. clarkii transcript revealed an 85 amino 315 acid full-length prehormone (Procl-pre-EH; Fig. 2I). A single 58 amino acid isoform of EH was 316 predicted from Procl-pre-EH (Table 2 and Fig. 2I). Analysis of this EH isoform by DiANNA 317 suggests disulfide bridging between the first and fourth, second and third and fifth and sixth 318 cysteines of the peptide (Table 2). 
Translation of the $P$. leptodactylus transcript revealed an 88 amino acid full-length

320 protein (Ponle-pre-EH; Fig. 4G). A single 56 amino acid isoform of EH was predicted from this

321 prehormone (Table 3 and Fig. 4G), with disulfide bridging likely between its first and fourth,

322 second and third and fifth and sixth cysteines (Table 3).

\subsection{FMRFamide-like peptide}

Four transcripts, all from $P$. clarkii, were identified as encoding FLP precursors using the sequence of $P$. clarkii prepro-FLRFamide A (Accession No. BAE06262; Yasuda-Kamatani and Yasuda, 2006) as the input query (Table 1). Translation of one of these sequences revealed a 384 amino acid full-length preprohormone (Procl-prepro-FLP I; Fig. 2J1), while translation of the others revealed C-terminal partial proteins of 29, 166 and 158 amino acids, respectively. The shortest of the partial proteins is identical in sequence to the C-terminus of Procl-prepro-FLP I;

331 however, the two other partial proteins are distinct from the C-terminus of this full-length 332 precursor, as well as from one another. Thus, both the 166 and 158 amino acid partial proteins 333 are considered here to be parts of two distinct preprohormones and have been named Procl334 prepro-FLP II (Fig. 2J2) and Procl-prepro-FLP III (Fig. 2J2), respectively. Eighteen peptides 335 were predicted from Procl-prepro-FLP I (Table 2 and Fig. 2J1), including nine possessing 336 FMRFamide-like C-termini, i.e. -FLRFamide (seven peptides), -YLRFamide (one peptide) or 337 FPRFamide (one peptide). Of these FLPs, all but one are encoded as single copies within the 338 preprohormone; the exception, SRNFLRFamide, is present twice in Procl-prepro-FLP I (Table 2 339 and Fig. 2J1). The nine linker/precursor-related peptide predicted from Procl-prepro-FLP I 340 possess distinct structures (Table 2 and Fig. 2J1). Eight peptides were predicted from the extant 341 portion of Procl-prepro-FLP II (Table 2 and Fig. 2J2), including four FLPs and four distinct 
342 linker/precursor-related peptides. Of the FLPs, two are encoded as single copies (both distinct

343 from those predicted from Procl-prepro-FLP I), with two copies of SRNFLRFamide (a peptide

344 also predicted Procl-prepro-FLP I) present in the extant portion of Procl-prepro-FLP II (Table 2

345 and Fig. 2J2). Five distinct peptide were predicted from the extant portion of Procl-prepro-FLP

346 III (Table 2 and Fig. 2J3), including two members of the FLP family: GFSDKNFMRFamide and

347 GGHNVLRFamide. While the sequence of Procl-prepro-FLP I is similar to that of the two

348 known P. clarkii prepro-FLPs (i.e. Accession Nos. $\underline{\text { BAE06262 }}$ and $\underline{\text { BAE06263}}$; Yasuda-

349 Kamatani and Yasuda, 2006), it is distinct enough from both to likely represent the product of a

350 different gene (Fig. 3B). Similarly, the differences in the sequence of Procl-prepro-FLP II and

351 Procl-prepro-FLP III from each other and the other known P. clarkii prepro-FLPs suggest that

352 they too are likely to be encoded by distinct genes (alignments not shown).

\section{3.12. GSEFLamide}

355 A single $P$. clarkii transcript was identified as encoding a putative GSEFLamide

356 precursor using the sequence of Tigriopus californicus prepro-GSEFLamide Ia (Christie, 2014b)

357 as the input query (Table 1). Translation of this transcript revealed a 136 amino acid C-terminal

358 partial protein (Procl-prepro-GSEFLamide; Fig. 2K). Twelve peptides were predicted from the

359 extant portion of Procl-prepro-GSEFLamide (Table 2 and Fig. 2K), including seven possessing

360 the C-terminal motif -GSEFLamide (two copies of AVGSEFLamide and five copies of

361 AMGSEFLamide), the hallmark of the GSEFLamide family, as well as three variant

362 GSEFLamides (AMGAEFLamide, ATGLEFLNERVMGSELLamide and YMGSEFSamide) and

363 two distinct linker/precursor-related peptides. 
Two transcripts, one from P. clarkii and the other from P. leptodactylus, were identified

367 as encoding putative intocin precursors using the sequence of $L$. vannamei prepro-intocin

368 (Christie, 2014f) as the input query (Table 1). Translation of the P. clarkii transcript revealed a

36977 amino acid N-terminal partial preprohormone (Procl-prepro-intocin; Fig. 2L). Two distinct

370 peptides were predicted from the extant portion of Procl-prepro-intocin (Table 2 and Fig. 2L),

371 one of which, CFITNCPPGamide (a disulfide bridge between the position 1 and 6 cysteine

372 residues), possesses the structural hallmarks of the intocin family, i.e. an overall length of nine

373 amino acids, the structure $\mathrm{C} X X X \mathrm{NCP} X \mathrm{Gamide}$, and a disulfide bridge present between the

374 position 1 and 6 cysteine residues (Stafflinger et al., 2008). DiANNA analysis of the

375 linker/precursor-related protein derived from the extant portion of Procl-prepro-intocin,

376 SGASTQIARSRTCSSCGPGLRGRCLGPEICCGEEVGCFLATREA, suggests disulfide

377 bonding between the first and second, third and fifth, and fourth and sixth cysteines in this

378 peptide (Table 2).

379 Translation of the P. leptodactylus transcript revealed a 153 amino acid full-length

380 precursor protein (Ponle-prepro-intocin; Fig. 4H). Four distinct peptides were predicted from

381 Ponle-prepro-intocin (Table 3 and Fig. 4H), including CFITNCPPGamide (disulfide bonding

382 between the position 1 and 6 cysteines), which is the same isoform of intocin predicted from the

383 P. clarkii partial protein identified above. Each of the linker/precursor-related peptides derived

384 from Ponle-prepro-intocin is also predicted to possess disulfide bonding (Table 3), i.e. bridges

385 between the first and sixth, second and fourth and third and fifth cysteines in

386 SGASTQIARSRTCSSCGPGLRGRCLGPEICCGEGVGCFLATREA, between the first and

387 second cysteines in MCRAENLVPLTCTNTDLKTCGRLREamide and between the second and 
fifth and third and fourth cysteines in

CAASGLCCTEMKCEFDGSCVESREASVEDQQVERQRFAFLPNLSDDQWSL.

\subsection{Leucokinin}

Three transcripts, all from $P$. clarkii, were identified as encoding leucokinin precursors

393 using the sequence of Eucyclops serrulatus prepro-leucokinin (Christie, 2015b) as the input

394 query (Table 1). Translation of this set of transcripts revealed one to encode a 356 amino acid

395 N-terminal partial protein, and the remaining two internal protein fragments of 155 and 154

396 amino acids, respectively. The two internal fragments share a common eight amino acid region

397 of overlap with the N-terminal partial protein, though both are distinct sequences. For

398 convenience of discussion the longer of the two internal fragments has been combined with the

399 N-terminal partial protein to produce a 503 amino acid N-terminal sequence, named here Procl-

400 prepro-leucokinin I (Fig. 2M1), with the 154 amino acid fragment named Procl-prepro-

401 leucokinin II (Fig. 2M2). Twenty-seven distinct peptides were predicted from the extant portion

402 of Procl-prepro-leucokinin I (Table 2 and Fig. 2M1), ten of which possess the C-terminal motif -

403 FXXWA/Gamide, which is the hallmark of the leucokinin family (Christie et al., 2010c). One of

404 the linker/precursor-related peptides derived from Procl-prepro-leucokinin I,

405 QGTDVSPLALPGGQPSPPCLPYRLPTHPLIRCELS, is predicted by DiANNA to possess a

406 disulfide bridge between its two cysteine residues. Thirteen peptides were predicted from the

407 extant portion of Procl-prepro-leucokinin II (Table 2 and Fig. 2M1), six of which possess

408 structures consistent with their inclusion as members of the leucokinin family. Of the peptides

409 derived from Procl-prepro-leucokinin II, all but three, one isoform of leucokinin and two

410 linker/precursor-related peptides, were also predicted from Procl-prepro-leucokinin I (Fig. 2M). 
412 3.15. Myosuppressin

413 A single $P$. leptodactylus transcript was identified as encoding a putative myosuppressin

414 precursor using the sequence of $H$. americanus prepro-myosuppressin (Accession No.

415 ACX46385; Stevens et al., 2009) as the input query (Table 1). Translation of this transcript

416 revealed a 99 amino acid full-length preprohormone (Ponle-prepro-myosuppressin; Fig. 4I).

417 Four peptides were predicted from Ponle-prepro-myosuppressin (Table 3 and Fig. 4I), including 418 pQDLDHVFLRFamide, a known and broadly conserved crustacean isoform of myosuppressin

419 (Christie et al., 2010c).

420

421 3.16. Neuroparsin

422 Six transcripts, two from P. clarkii, three from P. leptodactylus and one from $C$.

423 quadricarinatus, were identified as encoding putative neuroparsin precursors using the sequence

424 of the lobster Jasus lalandii pre-neuroparsin (Accession No. AHG98659; Marco et al., 2014) as

425 the input query (Table 1). Translation of the two $P$. clarkii sequences revealed one to encode a

42695 amino acid C-terminal partial protein (Procl-pre-neuroparsin I; Fig. 2N1), and the other a 101

427 amino acid full-length prehormone (Procl-pre-neuroparsin II; Fig. 2N2). A single peptide was

428 predicted from each of the $P$. clarkii pre-neuroparsins:

429 SPLCPERNEITPEDLNTCKYGVVLGWCGNPACGKGPGDPCGGRWEENGICGEGMYCVC

430 GYCAGCTTTLECALGRFC (disulfide bridges predicted between the first and twelfth, second

431 and tenth, third and sixth, fourth and ninth, fifth and seventh and eighth and eleventh cysteines)

432 from Procl-pre-neuroparsin I (Table 2 and Fig. 2N1) and

433 APRCEHHDRPPPNNCKYGTVRDWCRNGVCAKGPGESCGGNWFEQGKCGMGTFCQCG 
434 VCTGCSTVDGSCANGHLMC (disulfide bridges predicted between the first and eighth, second 435 and fourth, third and seventh, fifth and sixth, ninth and eleventh, and tenth and twelfth cysteines) 436 from Procl-pre-neuroparsin II (Table 2 and Fig. 2N2).

437 Translation of the three P. leptodactylus transcripts revealed one to encode a 107 amino 438 acid full-length prehormone (Ponle-pre-neuroparsin I; Fig. 4J1), and the other two, identical 101

439 amino acid precursor proteins (Ponle-pre-neuroparsin II; Fig. 4J2). Like the P. clarkii pre440 neuroparsins, each of the P. leptodactylus proteins is predicted to give rise to a single isoform of 441 neuroparsin:

442 SPLCPERNEITPEDLNTCKYGVVLGWCGNAACGKGPGDSCGGRWEENGICGEGMYCVC

443 GYCAGCTTTLECALGRFC (bridging predicted between the first and twelfth, second and tenth,

444 third and sixth, fourth and ninth, fifth and seventh and eighth and eleventh cysteines) from

445 Ponle-pre-neuroparsin I (Table 2 and Fig. 4J1) and

446 APRCDHHDRPPPNNCKYGTVRNWCRNGVCAKGPGESCGGHWYEQGKCGIGTFCLCGI

447 CIGCSTIDGSCADGPLIC (bridging predicted between the first and tenth, second and fourth, 448 third and seventh, fifth and sixth, eighth and eleventh, and ninth and twelfth cysteines) from

449 Ponle-pre-neuroparsin II (Table 2 and Fig. 4J2); these proteins are nearly identical in sequence to 450 their $P$. clarkii counterparts (P. leptodactylus neuroparsin I differs from $P$. clarkii neuroparsin I 451 at just two residues [both conservative amino acid substitutions], while P. leptodactylus 452 neuroparsin II differs from P. clarkii neuroparsin II at 12 positions [nine of 12 being 453 conservative substitutions]).

454 Translation of the C. quadricarinatus transcript revealed a 101 amino acid full-length 455 prehormone (Chequ-pre-neuroparsin; Fig. 5B). As with the other pre-neuroparsin discussed 456 earlier, a single neuroparsin isoform was predicted from Chequ-pre-neuroparsin (Table 4 and 
Fig. 5B):

APRCNTHDRPPPSNCKYGTVRNWCRNGVCAKAPGESCGGHWYEHGKCGIGTFCLCGV

CIGCSTIDGRCADGPLMC (disulfide bridging predicted between the first and eighth, second

460 and fourth, third and seventh, fifth and sixth, ninth and twelfth, and tenth and eleventh cysteines).

461 This peptide appears to be the counterpart of $P$. clarkii and P. leptodactylus neuroparsin II,

462 differing from the former protein at 15 residues (ten of which are conservative substitutions) and

463 from the latter sequence at eight positions (six being conservative substitutions).

\subsection{Neuropeptide F}

Two transcripts, both from $P$. clarkii, were identified as encoding putative NPF

467 precursors using the sequence of L. vannamei prepro-NPF I (Accession No. AEC12204; Christie

468 et al., 2011d) as the input query (Table 1). Translation of one transcript revealed a 104 amino

469 acid full-length precursor (Procl-prepro-NPF I; Fig. 2O1), while translation of the other revealed

470 a 56 amino acid N-terminal partial protein (Procl-prepro-NPF II; Fig. 2O2). Two distinct

471 peptides were predicted from Procl-prepro-NPF I (Table 2 and Fig. 2O1), including

472 VASGGRHDSSAADALQAMHEAAIAGLLGPTEIQYPNRPNMFKSPVELRQYLDALNAYY

473 AIAGRPRFamide, a peptide possessing structural homology to member of the NPF family, i.e.

474 an overall length of 30 or more amino acids, the C-terminal motif -GRPRFamide, and tyrosine

475 residues at positions 10 and 17 from the C-terminus (Christie et al., 2010c). A single partial

476 peptide was predicted from Procl-prepro-NPF II (Table 2 and Fig. 2O2). This partial sequence,

477 KPDPTELAAMADAIKYLQELTKYYSQVSRP+, is highly similar to that of the N-terminus of

478 NPF isoform predicted from the L. vannamei query (differing at just six residues, four of which

479 are conservative amino acid substitutions), and thus likely represents a portion of an NPF 
480 isoform distinct from that derived from Procl-prepro-NPF I (Table 2 and Fig. 2O). Given the

481 conserved structure of NPF isoform, it is likely that the full-length peptide derived from Procl-

482 prepro-NPF II will ultimately be determined to be

483 KPDPTELAAMADAIKYLQELTKYYSQVSRPRFamide.

\subsection{Pigment dispersing hormone}

A single $P$. clarkii transcript was identified as encoding a putative PDH precursor using the sequence of a PDH preprohormone from the crayfish Orconectes limosus (Accession No.

488 AAB26385; de Kleijn et al., 1993) as the input query (Table 1). Translation of this transcript 489 revealed a 51 amino acid C-terminal partial protein (Procl-prepro-PDH; Fig. 2P). Two distinct 490 peptides were predicted from Procl-prepro-PDH (Table 2 and Fig. 2P), one of which, 491 NSELLNTLLGSQGLSNMRSAamide, possesses structural similarity to members of the PDH 492 family (Christie et al., 2010c).

\subsection{Pyrokinin}

495 A single $P$. clarkii transcript was identified as encoding a pyrokinin precursor using the 496 partial sequence of L. vannamei prepro-CAPA (Christie, 2014f) as the query sequence (Table 1).

497 Translation of this transcript revealed a 75 amino acid C-terminal partial protein (Procl-prepro498 pyrokinin; Fig. 2Q). Six peptides (five full-length and one partial) were predicted from Procl499 prepro-pyrokinin (Table 2 and Fig. 2Q), all of which possess C-terminal motifs similar to 500 LXXPRXamide, the hallmark of the CAPA/periviscerokinin/pyrokinin superfamily (Christie et 501 al., 2010c). 
A single $P$. leptodactylus transcript was identified as encoding a RPCH precursor using the sequence of $C$. quadricarinatus prepro-RPCH (Accession No. AAV80404; Martinez-Perez et al., 2007) as the input query (Table 1). Translation of this transcript revealed a 95 amino acid Cterminal partial protein (Ponle-prepro-RPCH; Fig. 4K). Three distinct peptides were predicted from Ponle-prepro-RPCH (Table 3 and Fig. 4K), including pQLNFSPGWamide, a peptide whose structure is identical to authentic RPCH (Christie et al., 2010c).

\subsection{RYamide}

A single $P$. clarkii transcript was identified as encoding a putative RYamide precursor

513 using the partial sequence of L. vannamei prepro-RYamide (Christie, 2014f) as the input query

514 (Table 1). Translation of this transcript revealed a 134 amino acid full-length preprohormone

515 (Procl-prepro-RYamide; Fig. 2R). Six distinct peptides were predicted from Procl-prepro-

516 RYamide (Table 2 and Fig. 2R), two of which, pQGFYSQRYamide and FIGGSRYamide,

517 possess the -RYamide C-terminus that is the hallmark of members of the RYamide family

518 (Christie et al., 2010c). Analysis of one of the linker/precursor-related peptide predicted from

519 Procl-prepro-RYamide,

520 SGSPPESSEFSSAITPEADDTDMTATLLLGDSVLCFLVDVPDIYRCL, suggests the presence 521 of a disulfide bond between its two cysteine residues (Table 2).

523 3.22. Short neuropeptide $F$

524 Two transcripts, one from P. clarkii and the other from P. leptodactylus, were identified 525 as encoding SNPF precursors using the sequence of $D$. pulex prepro-sNPF (Accession No. 
526 EFX90018; Colbourne et al., 2011) as the input query (Table 1). Translation of the $P$. clarkii

527 transcript revealed a 129 amino acid full-length preprohormone (Procl-prepro-sNPF; Fig. 2S).

528 Six distinct peptides were predicted from Procl-prepro-sNPF (Table 2 and Fig. 2S), including

529 three, APPSMRLRFamide, DMGWQVAQRSMPSLRLRFamide and DSRTPALRLRFamide,

530 that possess the structural hallmarks of members of the SNPF family, i.e. the C-terminal motif -

531 RXRFamide and an overall length of ten or so amino acids (Christie et al., 2010c).

532 Translation of the P. leptodactylus transcript revealed a 128 amino acid full-length

533 protein (Ponle-prepro-sNPF; Fig. 4L). Like the P. clarkii precursor, six distinct peptides were

534 predicted from Ponle-prepro-sNPF (Table 3 and Fig. 4L), including the sNPFs

535 APPSMRLRFamide, DMGWQVAQRSMPSLRLRFamide and DSRMPALRLRFamide, the

536 former two of which were also predicted from Procl-prepro-sNPF.

537

538 3.23. SIFamide

539 A single $P$. clarkii transcript was identified as encoding a putative SIFamide precursor

540 using the sequence of $H$. americanus prepro-Val ${ }^{1}$-SIFamide (Accession No. ABV21807;

541 Dickinson et al., 2008) as the input query (Table 1). Translation of this transcript revealed a 76

542 amino acid full-length preprohormone (Procl-prepro-SIFamide; Fig. 2T), which is identical in

543 sequence to a known P. clarkii SIFamide precursor (i.e. Accession No. BAC55940; Yasuda et

544 al., 2004 [Fig. 3C]). Two peptides were predicted from Procl-prepro-SIFamide (Table 2 and Fig.

$5452 \mathrm{~T}$ ), one of which, GYRKPPFNGSIFamide, is a known and broadly conserved crustacean

546 SIFamide isoform (Christie et al., 2010c).

548 3.24. Sulfakinin 
A single $P$. clarkii transcript was identified as encoding a putative sulfakinin precursor

550 using the sequence of $H$. americanus prepro-sulfakinin (Accession No. ABQ95346; Dickinson et

551 al., 2007) as the input query (Table 1). Translation of this transcript revealed a 103 amino acid

552 C-terminal partial protein (Procl-prepro-sulfakinin; Fig. 1C). Six distinct peptides were

553 predicted from the extant portion of Procl-prepro-sulfakinin, including two,

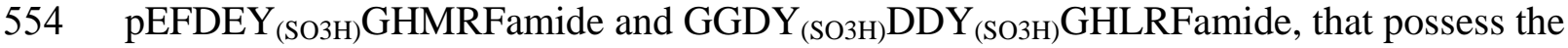
555 structural hallmark of the sulfakinin family, i.e. the C-terminal motif $-\mathrm{Y}_{(\mathrm{SO} \mathrm{H})} \mathrm{GHM} / \mathrm{LRFamide}$

556 (Christie et al., 2010c).

\subsection{Tachykinin-related peptide}

Two transcripts, one from $P$. clarkii and the other from $P$. leptodactylus, were identified

560 as encoding putative TRP precursors using the sequence of $H$. americanus prepro-TRP

561 (Accession No. $\underline{\text { ACB41786; }}$, Christie et al., 2008a) as the input query (Table 1). Translation of 562 the $P$. clarkii transcript revealed a 225 amino acid full-length preprohormone (Procl-prepro-TRP;

563 Fig. 2U), which is identical in sequence to a known $P$. clarkii TRP precursor (i.e. Accession No.

564 BAC82426; Yasuda-Kamatani and Yasuda, 2004 [Fig. 3D]). Twelve peptides were predicted

565 from Procl-prepro-TRP (Table 2 and Fig. 2U), including seven copies of APSGFLGMRamide, a

566 known and broadly conserved crustacean TRP (Christie et al., 2010c). The five linker/precursor-

567 related peptide derived from Procl-prepro-TRP possess distinct structures (Table 2 and Fig. 2U).

568 Translation of the $P$. leptodactylus transcript revealed a 73 amino acid internal protein

569 fragment (Ponle-prepro-TRP; Fig. 4M). Five peptides were predicted from Ponle-prepro-TRP

570 (Table 3 and Fig. 4M), including three copies of APSGFLGMRamide and two distinct

571 linker/precursor-related peptides (one full-length and one partial). 


\section{4. Discussion}

\section{4.1. Prediction of crayfish peptidomes using transcriptome shotgun assembly data}

575 In silico genome/transcriptome mining has been, and continues to be, a powerful method 576 for neuropeptide discovery in crustaceans (e.g. Christie, 2014a, 2014b, 2014c, 2014d, 2014e,

577 2014f, 2015b; Christie et al., 2008b, 2010a, 2011c, 2013; Dircksen et al., 2011; Gard et al., 2009;

578 Ma et al., 2009b, 2010; Toullec et al., 2013; Ventura et al., 2014; Yan et al., 2012). When a

579 large collection of assembled nucleotide sequences is available for a species, an extensive 580 peptidome can rapidly be deduced using a simple bioinformatics workflow, e.g. the 158 distinct 581 mature peptides recently identified from the penaeid shrimp L. vannamei (Christie, 2014f). In 582 the study presented here, the publicly accessible TSA sequences for members of the Astacidea 583 were mined for putative neuropeptide-encoding transcripts using the BLAST algorithm tblastn 584 and known crustacean pre/preprohormones as input queries. Peptide-encoding sequences from 585 three crayfish were identified via this strategy: P. clarkii (33 transcripts), P. leptodactylus (17

586 transcripts) and C. quadricarinatus (two transcripts); these three species encompass the two 587 extant superfamilies of the freshwater crayfish, namely the Astacoidea (P. clarkii and $P$. 588 leptodactylus) and the Parastacoidea (C. quadricarinatus), as well as the three extant families of 589 these astacidean subgroups, i.e. the Astacidae (P. leptodactylus), the Cambaridae (P. clarkii), and 590 the Parastacidae (C. quadricarinatus).

$591 \quad$ Translation of the 33 P. clarkii transcripts allowed for the structural prediction of 176 592 distinct peptides, including isoforms of ACP, AST-A, AST-B, AST-C, bursicon $\alpha$, bursicon $\beta$, 593 CCHamide, CHH/ITP, DH31, EH, FLP, GSEFLamide, intocin, leucokinin, neuroparsin, NPF, 594 PDH, pyrokinin, RYamide, sNPF, SIFamide, sulfakinin and TRP. This collection of sequences 
595 is one of, if not the, largest peptidome thus far deduced via in silico transcriptome mining for any

596 single crustacean species, significantly expanding the catalog of peptidergic signaling agents for

597 P. clarkii, as well as for the Astacidea, and even the Decapoda, generally. Likewise, the 46

598 distinct P. leptodactylus peptides predicted here, which include members of AST-A, AST-C,

599 bursicon $\alpha$, CCHamide, CHH/ITP, DH31, EH, intocin, myosuppressin, neuroparsin, RPCH,

600 sNPF and TRP families, are of significance as they are the first peptides predicted for this

601 species, and in conjunction with the $P$. clarkii sequences, include isoforms of peptide families

602 previously unknown from the Astacidea (see below). While just two peptides were predicted for

603 C. quadricarinatus, the identification of a neuroparsin from this species is the first from any

604 member of the Astacidea (isoforms of this peptide family were also predicted from P. clarkii and

605 P. leptodactylus). Taken collectively, the structural data presented here not only greatly expand

606 the catalog of neuropeptides known for the Astacidea, but also provide platforms for future

607 anatomical studies of neuropeptide distribution in crayfish and for assessment of the functional

608 roles played by peptidergic signaling systems in astacideans.

609

610 4.2. Identification of the first members of the CCHamide, eclosion hormone, GSEFLamide,

611 intocin, neuroparsin and RYamide families from the Astacidea

612 A wide array of peptides was identified in this study, particularly from P. clarkii. While

613 most of the peptides predicted here are novel, at least for the species from which they were

614 identified, isoforms of many of them, including some identical sequences, have been described

615 from other members of the Astacidea, particularly from P. clarkii itself (e.g. Yasuda et al., 2004;

616 Yasuda-Kamatani and Yasuda, 2004, 2006) and/or from the lobster H. americanus (e.g. Cape et

617 al., 2008; Chen et al., 2010; Fu et al., 2005a; Jia et al., 2014; Jiang et al., 2012; Ma et al., 2008). 
618 Specifically, members of the AST-A, AST-B, AST-C, bursicon $\alpha$, bursicon $\beta$, CHH/ITP, DH31, 619 FLP, leucokinin, myosuppressin, NPF, PDH, pyrokinin, RPCH, sNPF, SIFamide, sulfakinin and

620 TRP families have all been identified from at least one astacidean prior to this study. In contrast, 621 the isoforms of CCHamide, EH, GSEFLamide, intocin, neuroparsin and RYamide predicted 622 here, while known from other decapods, are the firsts for the Astacidea. Specifically, CCHamide 623 (predicted in this study from both P. clarkii and P. leptodactylus) was identified previously from 624 the penaeid shrimp L. vannamei and Penaeus monodon (Christie, 2014f), while isoforms of EH 625 (predicted here from both $P$. clarkii and $P$. leptodactylus) are known from both of these shrimp 626 (Christie, 2014f; Christie et al., 2010a), as well as from the penaeid Marsupenaeus japonicus 627 (Christie et al., 2010a) and the brachyuran crab Callinectes sapidus (Christie et al., 2010a). 628 Members of the GSEFLamide family (predicted here from $P$. clarkii) were previously described 629 from the penaeids L. vannamei and M. japonicus (Christie, 2014b, 2014f) and the brachyuran 630 Eriocheir sinensis (Christie, 2014b), while intocin (predicted here from both $P$. clarkii and $P$. 631 leptodactylus) was known from L. vannamei (Christie, 2014f). Neuroparsins (predicted in this 632 study from P. clarkii, P. leptodactylus and C. quadricarinatus) have been identified from a 633 number of decapods, including the penaeid shrimp L. vannamei, M. japonicus and P. mondon 634 (Christie, 2014f; Christie et al., 2010a; Ma et al., 2010), the brachyuran C. sapidus (Christie et 635 al., 2010a), the anomuran Petrolisthes cinctipes (Christie et al., 2010a), and the palinuran $J$. 636 lalandii (Marco et al., 2014). Similarly, members of the RYamide family (predicted here from 637 P. clarkii) have been identified from a variety of decapods (e.g. Christie, 2014f; Fu et al., 2005b; 638 Hui et al., 2013; Li et al., 2003; Ma et al., 2009b, 2010; Stemmler et al., 2007b). At present, how 639 members of these peptides families are distributed in the nervous systems of astacideans, or for 640 that matter any decapod, remains unknown, as are functional roles they may play in these 
641 animals. While nothing is currently known about the functional roles played by members of the

642 GSEFLamide or RYamide families in any arthropod, work in insects suggest that the crustacean

643 CCHamides may be involved in the regulation of feeding-related behaviors (Ida et al., 2012; Li

644 et al., 2013) and/or the modulation of olfaction (Farhan et al., 2013), while the EHs may play a

645 role in the control of molting (e.g. Mesce and Fahrbach, 2002; Truman, 2005; Zitnan et al., 2007)

646 and intocin in the regulation of diuresis (Aikins et al., 2008). In insects, the neuroparsins have

647 been shown to play roles in reproductive control (e.g. Badisco et al., 2007), and they may well

648 serve similar function in the Crustacea (Yang et al., 2014).

650 4.3. Identification of the first adipokinetic hormone-corazonin-like peptide from a member of the

651 Decapoda

652 One of the highlights of this study was the prediction of an isoform of ACP,

653 pQITFSRSWVPQamide, from the crayfish P. clarkii. This discovery is not only the first

654 detection of an isoform of this peptide family in a member of the Astacidea, but is also the first

655 description of an ACP from any member of the Decapoda. This peptide family is proposed as a

656 structural intermediate between the adipokinetic hormone and corazonin families (Hansen et al.,

6572010 [Fig. 6A]), and thus the origin of it being named adipokinetic hormone-corazonin-like

658 peptide or ACP. At the time of its discovery, the ACP family was proposed as hexapod-specific

659 (Hansen et al., 2010), as isoforms of it, as well as its receptor, appeared broadly conserved in

660 insects, but were absent in the genome of the cladoceran crustacean D. pulex, the only crustacean

661 for which a fully sequenced genome was available (Colbourne et al., 2011), and one of just a few

662 crustaceans for which significant transcriptomic resources were publicly extant. With the recent

663 public deposition of a number of large TSA datasets for members of the Crustacea, the first 
664 isoforms of ACP from this subphylum have recently been discovered (Fig. 6B), the first from the

665 remipede $S$. cf. tulumensis (Christie, 2014a) and subsequently from the copepods T. californicus

666 (Christie, 2014b) and E. serrulatus (2015b). Interestingly, the copepod and P. clarkii isoforms

667 of ACP are longer than the known insect/remipede variants (Fig. 6B), being 11-13 amino acids

668 in length rather than the stereotypical 10 residues (Christie, 2014a; Hansen et al., 2010). Also of

669 note, two isoforms of ACP are present in each of the known copepod preprohormone (Fig. 6C),

670 whereas just a single isoform is present in the insects, remipede and crayfish precursors (Christie,

$6712014 a$; Hansen et al., 2010 [Fig. 6C]). While nothing is currently known about the distribution

672 or function of ACPs in crustaceans, in insects, members of this peptide family are present in

673 neuronal somata in the brain and in axons and neuropil in the ventral nerve chord (Hansen et al.,

674 2010; Patel et al., 2014). The organization of the neuronal ACP release sites in insects suggests a

675 local endocrine (paracrine) role for this peptide, most likely functioning as a locally released

676 neuromodulator (Hansen et al., 2010; Patel et al., 2014).

677

678 4.4. Summary

679 The Astacidea is a decapod crustacean infraorder of both commercial and biomedical

680 importance. While members of this taxon have been the subjects of numerous peptide discovery

681 studies, none has involved large-scale transcriptome mining. Here, such an investigation was

682 undertaken, with peptide-encoding transcripts identified for three crayfish species: P. clarkii, $P$.

683 leptodactylus and C. quadricarinatus. The extant TSA data for P. clarkii alone allowed for the

684 prediction of 176 distinct peptides, which represent one of, if not the largest peptidome thus far

685 predicted via in silico transcriptome mining for any single crustacean species. The peptides

686 predicted here encompass 25 distinct peptide families, and include the first astacidean isoforms 
687 of CCHamide, EH, GSEFLamide, intocin, neuroparsin and RYamide, as well as the first member

688 of the ACP family predicted from any decapod. These data more than double the catalog of

689 known astacidean peptides, and serve as a resource for future functional studies of peptidergic

690 signaling in members of the Astacidea and other crustacean taxa.

691

\section{Acknowledgements}

693 Financial support was provided by National Science Foundation grant IOS-1353023 and 694 the Cades Foundation of Honolulu, Hawaii.

695

696 References

697 Aikins, M.J., Schooley, D.A., Begum, K., Detheux, M., Beeman, R.W., Park, Y., 2008.

698 Vasopressin-like peptide and its receptor function in an indirect diuretic signaling pathway in the 699 red flour beetle. Insect Biochem. Mol. Biol. 2008 38, 740-748.

700

701 Badisco, L., Claeys, I., Van Loy, T., Van Hiel, M., Franssens, V., Simonet, G., Vanden Broeck, 702 J., 2007. Neuroparsins, a family of conserved arthropod neuropeptides. Gen. Comp. Endocrinol. $703 \quad 153,64-71$.

704

705 Baierlein, B., Thurow, A.L., Atwood, H.L., Cooper, R.L., 2011. Membrane potentials, synaptic 706 responses, neuronal circuitry, neuromodulation and muscle histology using the crayfish: student 707 laboratory exercises. J. Vis. Exp. 47.

708 
709 Barbaresi, S., Tricarico, E., Gherardi, F., 2004. Factors inducing the intense burrowing activity

710 of the red-swamp crayfish, Procambarus clarkii, an invasive species. Naturwissenschaften 91,

$711342-345$.

712

713 Böcking, D., Dircksen, H., Keller, R., 2002. The crustacean neuropeptide of the CHH/MIH/GIH

714 family: structures and biological activities. In: The Crustacean Nervous System. K Wiese (Ed.).

715 Springer, Heidelberg. pp. 84-97.

716

717 Bracken-Grissom, H.D., Ahyong, S.T., Wilkinson, R.D., Feldmann, R.M., Schweitzer, C.E.,

718 Breinholt, J.W., Bendall, M., Palero, F., Chan, T.Y., Felder, D.L., Robles, R., Chu, K.H., Tsang,

719 L.M., Kim, D., Martin, J.W., Crandall, K.A., 2014. The emergence of lobsters: phylogenetic

720 relationships, morphological evolution and divergence time comparisons of an ancient group

721 (decapoda: achelata, astacidea, glypheidea, polychelida). Syst. Biol. 63, 457-479.

722

723 Bulau, P., Meisen, I., Schmitz, T., Keller, R., Peter-Katalinić, J., 2004. Identification of

724 neuropeptides from the sinus gland of the crayfish Orconectes limosus using nanoscale on-line

725 liquid chromatography tandem mass spectrometry. Mol. Cell. Proteomics 3, 558-564.

726

727 Cape, S.S., Rehm, K.J., Ma, M., Marder, E., Li, L., 2008. Mass spectral comparison of the

728 neuropeptide complement of the stomatogastric ganglion and brain in the adult and embryonic

729 lobster, Homarus americanus. J. Neurochem. 105, 690-702. 
731 Chen, R., Jiang, X., Conaway, M.C., Mohtashemi, I., Hui, L., Viner, R., Li, L., 2010. Mass

732 spectral analysis of neuropeptide expression and distribution in the nervous system of the lobster

733 Homarus americanus. J. Proteome Res. 9, 818-832.

734

735 Christie, A.E., 2008a. Neuropeptide discovery in Ixodoidea: an in silico investigation using

736 publicly accessible expressed sequence tags. Gen. Comp. Endocrinol. 157, 174-185.

737

738 Christie, A.E., 2008b. In silico analyses of peptide paracrines/hormones in Aphidoidea. Gen.

739 Comp. Endocrinol. 159, 67-79.

740

741 Christie, A.E., 2014a. Prediction of the first neuropeptides from a member of the Remipedia

742 (Arthropoda, Crustacea). Gen. Comp. Endocrinol. 201, 74-86.

743

744 Christie, A.E., 2014b. Prediction of the peptidomes of Tigriopus californicus and

745 Lepeophtheirus salmonis (Copepoda, Crustacea). Gen. Comp. Endocrinol. 201, 87-106.

746

747 Christie, A.E., 2014c. Peptide discovery in the ectoparasitic crustacean Argulus siamensis:

748 identification of the first neuropeptides from a member of the Branchiura. Gen. Comp.

749 Endocrinol. 204, 114-125.

750

751 Christie, A.E., 2014d. In silico characterization of the peptidome of the sea louse Caligus

752 rogercresseyi (Crustacea, Copepoda). Gen. Comp. Endocrinol. 204, 248-260. 
754 Christie, A.E., 2014e. Identification of the first neuropeptides from the Amphipoda (Arthropoda,

755 Crustacea). Gen. Comp. Endocrinol. 206, 96-110.

756

757 Christie, A.E., 2014f. Expansion of the Litopenaeus vannamei and Penaeus monodon

758 peptidomes using transcriptome shotgun assembly sequence data. Gen. Comp. Endocrinol. 206, $759 \quad 235-254$.

760

761 Christie, A.E., 2015a. In silico characterization of the neuropeptidome of the Western black

762 widow spider Latrodectus hesperus. Gen. Comp. Endocrinol. 210, 63-80.

763

764 Christie, A.E., 2015b. Neuropeptide discovery in Eucyclops serrulatus (Crustacea, Copepoda): in 765 silico prediction of the first peptidome for a member of the Cyclopoida. Gen. Comp. Endocrinol. $766211,92-105$.

767

768 Christie, A.E., Cashman, C.R., Brennan, H.R., Ma, M., Sousa, G.L., Li, L., Stemmler, E.A., 769 Dickinson, P.S., 2008b. Identification of putative crustacean neuropeptides using in silico 770 analyses of publicly accessible expressed sequence tags. Gen. Comp. Endocrinol. 156, $246-64$. 771

772 Christie, A.E., Cashman, C.R., Stevens, J.S., Smith, C.M., Beale, K.M., Stemmler, E.A.,

773 Greenwood, S.J., Towle, D.W., Dickinson, P.S., 2008a. Identification and cardiotropic actions

774 of brain/gut-derived tachykinin-related peptides (TRPs) from the American lobster Homarus

775 americanus. Peptides 29, 1909-1918. 
777 Christie, A.E., Chapline, M.C., Jackson, J.M., Dowda, J.K., Hartline, N., Malecha, S.R., Lenz,

778 P.H., 2011d. Identification, tissue distribution and orexigenic activity of neuropeptide F (NPF)

779 in penaeid shrimp. J. Exp. Biol. 214, 1386-1396.

780

781 Christie, A.E., Chi, M., 2015. Neuropeptide discovery in the Araneae (Arthropoda, Chelicerata,

782 Arachnida): elucidation of true spider peptidomes using that of the Western black widow as a

783 reference. Gen. Comp. Endocrinol. 213, 90-109.

784

785 Christie, A.E., Durkin, C.S., Hartline, N., Ohno, P., Lenz, P.H., 2010a. Bioinformatic analyses

786 of the publicly accessible crustacean expressed sequence tags (ESTs) reveal numerous novel

787 neuropeptide-encoding precursor proteins, including ones from members of several little studied 788 taxa. Gen. Comp. Endocrinol. 167, 164-178.

789

790 Christie, A.E., McCoole, M.D., Harmon, S.M., Baer, K.N., Lenz, P.H., 2011c. Genomic

791 analyses of the Daphnia pulex peptidome. Gen. Comp. Endocrinol. 171, 131-150.

792

793 Christie, A.E., Nolan, D.H., Garcia, Z.A., McCoole, M.D., Harmon, S.M., Congdon-Jones, B.,

794 Ohno, P., Hartline, N., Congdon, C.B., Baer, K.N., Lenz, P.H., 2011b. Bioinformatic prediction

795 of arthropod/nematode-like peptides in non-arthropod, non-nematode members of the

796 Ecdysozoa. Gen. Comp. Endocrinol. 170, 480-486.

797 
798 Christie, A.E., Nolan, D.H., Ohno, P., Hartline, N., Lenz, P.H., 2011a. Identification of

799 chelicerate neuropeptides using bioinformatics of publicly accessible expressed sequence tags.

800 Gen. Comp. Endocrinol. 170, 144-155.

801

802 Christie, A.E., Roncalli, V., Wu, L.S., Ganote, C.L., Doak, T., Lenz, P.H., 2013. Peptidergic

803 signaling in Calanus finmarchicus (Crustacea, Copepoda): in silico identification of putative

804 peptide hormones and their receptors using a de novo assembled transcriptome. Gen. Comp.

805 Endocrinol. 187:117-35.

806

807 Christie, A.E., Stemmler, E.A., Dickinson, P.S., 2010c. Crustacean neuropeptides. Cell. Mol. $808 \quad$ Life Sci. 67, 4135-4169.

809

810 Christie, A.E., Stemmler, E.A., Peguero, B., Messinger, D.I., Provencher, H.L., Scheerlinck, P., 811 Hsu, Y.W., Guiney, M.E., de la Iglesia, H.O., Dickinson, P.S., 2006. Identification,

812 physiological actions, and distribution of VYRKPPFNGSIFamide (Val1)-SIFamide) in the

813 stomatogastric nervous system of the American lobster Homarus americanus. J. Comp. Neurol. 814 496, 406-421.

815

816 Christie, A.E., Stevens, J.S., Bowers, M.R., Chapline, M.C., Jensen, D.A., Schegg, K.M.,

817 Goldwaser, J., Kwiatkowski, M.A., Pleasant, T.K. Jr., Shoenfeld, L., Tempest, L.K., Williams, 818 C.R., Wiwatpanit, T., Smith, C.M., Beale, K.M., Towle, D.W., Schooley, D.A., Dickinson, P.S., 819 2010b. Identification of a calcitonin-like diuretic hormone that functions as an intrinsic 
820 modulator of the American lobster, Homarus americanus, cardiac neuromuscular system. J.

821 Exp. Biol. 213, 118-127.

822

823 Colbourne, J.K., Pfrender, M.E., Gilbert, D., Thomas, W.K., Tucker, A., Oakley, T.H.,

824 Tokishita, S., Aerts, A., Arnold, G.J., Basu, M.K., Bauer, D.J., Cáceres, C.E., Carmel, L., Casola,

825 C., Choi, J.H., Detter, J.C., Dong, Q., Dusheyko, S., Eads, B.D., Fröhlich, T., Geiler-Samerotte,

826 K.A., Gerlach, D., Hatcher, P., Jogdeo, S., Krijgsveld, J., Kriventseva, E.V., Kültz, D., Laforsch,

827 C., Lindquist, E., Lopez, J., Manak, J.R., Muller, J., Pangilinan, J., Patwardhan, R.P., Pitluck, S.,

828 Pritham, E.J., Rechtsteiner, A., Rho, M., Rogozin, I.B., Sakarya, O., Salamov, A., Schaack, S.,

829 Shapiro, H., Shiga, Y., Skalitzky, C., Smith, Z., Souvorov, A., Sung, W., Tang, Z., Tsuchiya, D.,

830 Tu, H., Vos, H., Wang, M., Wolf, Y.I., Yamagata, H., Yamada, T., Ye, Y., Shaw, J.R., Andrews,

831 J., Crease, T.J., Tang, H., Lucas, S.M., Robertson, H.M., Bork, P., Koonin, E.V., Zdobnov, E.M.,

832 Grigoriev, I.V., Lynch, M., Boore, J.L., 2011. The ecoresponsive genome of Daphnia pulex.

833 Science 331, 555-561.

834

835 Cooper, A.S., Leksrisawat, B., Gilberts, A.B., Mercier, A.J., Cooper, R.L., 2011. Physiological 836 experimentation with the crayfish hindgut: a student laboratory exercise. J. Vis. Exp. 47.

838 Crandall, K,A., Buhay, J.E., 2008. Global diversity of crayfish (Astacidae, Cambaridae, and 839 Parastacidae - Decapoda) in freshwater. Hydrobiologia 595, 295-301. 
841 Chung, J.S., Wilcockson, D.C., Zmora, N., Zohar, Y., Dircksen, H., Webster, S.G., 2006.

842 Identification and developmental expression of mRNAs encoding crustacean cardioactive

843 peptide (CCAP) in decapod crustaceans. J. Exp. Biol. 209, 3862-3872.

845 de Kleijn, D.P., de Leeuw, E.P., van den Berg, M.C., Martens, G.J., van Herp, F., 1995. Cloning

846 and expression of two mRNAs encoding structurally different crustacean hyperglycemic

847 hormone precursors in the lobster Homarus americanus. Biochim. Biophys. Acta. 1260, 62-66.

849 de Kleijn, D.P., Linck, B., Klein, J.M., Weidemann, W.M., Keller, R., van Herp, F., 1993.

850 Structure and localization of mRNA encoding a pigment dispersing hormone (PDH) in the

851 eyestalk of the crayfish Orconectes limosus. FEBS Lett. 321, 251-255.

852

853 Dickinson, P.S., Stemmler, E.A., Barton, E.E., Cashman, C.R., Gardner, N.P., Rus, S., Brennan,

854 H.R., McClintock, T.S., Christie, A.E., 2009a. Molecular, mass spectral, and physiological

855 analyses of orcokinins and orcokinin precursor-related peptides in the lobster Homarus

856 americanus and the crayfish Procambarus clarkii. Peptides 30, 297-317.

858 Dickinson, P.S., Stemmler, E.A., Cashman, C.R., Brennan, H.R., Dennison, B., Huber, K.E.,

859 Peguero, B., Rabacal, W., Goiney, C.C., Smith, C.M., Towle, D.W., Christie, A.E., 2008.

860 SIFamide peptides in clawed lobsters and freshwater crayfish (Crustacea, Decapoda, Astacidea):

861 a combined molecular, mass spectrometric and electrophysiological investigation. Gen. Comp.

862 Endocrinol. 156, 347-360. 
864 Dickinson, P.S., Stevens, J.S., Rus, S., Brennan, H.R., Goiney, C.C., Smith, C.M., Li, L., Towle, 865 D.W., Christie, A.E., 2007. Identification and cardiotropic actions of sulfakinin peptides in the 866 American lobster Homarus americanus. J. Exp. Biol. 210, 2278-2289.

868 Dickinson, P.S., Wiwatpanit, T., Gabranski, E.R., Ackerman, R.J., Stevens, J.S., Cashman, C.R.,

869 Stemmler, E.A., Christie, A.E., 2009b. Identification of SYWKQCAFNAVSCFamide: a

870 broadly conserved crustacean C-type allatostatin-like peptide with both neuromodulatory and

871 cardioactive properties. J. Exp. Biol. 212, 1140-1152.

872

873 Dircksen, H., Neupert, S., Predel, R., Verleyen, P., Huybrechts, J., Strauss, J., Hauser, F.,

874 Stafflinger, E., Schneider, M., Pauwels, K., Schoofs, L., Grimmelikhuijzen, C.J., 2011.

875 Genomics, transcriptomics, and peptidomics of Daphnia pulex neuropeptides and protein

876 hormones. J. Proteome Res. 10, 4478-4504.

877

878 Farhan, A., Gulati, J., Große-Wilde, E., Vogel, H., Hansson, B.S., Knaden, M., 2013. The

879 CCHamide 1 receptor modulates sensory perception and olfactory behavior in starved

880 Drosophila. Sci. Rep. 3, 2765.

881

882 Fénelon, V., Le Feuvre, Y., Bem, T., Meyrand, P., 2003. Maturation of rhythmic neural

883 network: role of central modulatory inputs. J. Physiol. Paris. 97, 59-68.

884

885 Ferrè, F., Clote, P., 2005. DiANNA: a web server for disulfide connectivity prediction. Nucleic 886 Acids Res. 33,W230-W232. 
888 Fu, Q., Goy, M.F., Li, L., 2005a. Identification of neuropeptides from the decapod crustacean 889 sinus glands using nanoscale liquid chromatography tandem mass spectrometry. Biochem.

890 Biophys. Res. Commun. 337, 765-778.

891

892 Fu, Q., Kutz, K.K., Schmidt, J.J., Hsu, Y.W., Messinger, D.I., Cain, S.D., de la Iglesia, H.O., 893 Christie, A.E., Li, L., 2005b. Hormone complement of the Cancer productus sinus gland and 894 pericardial organ: an anatomical and mass spectrometric investigation. J. Comp. Neurol. 493, $895 \quad 607-626$.

896

897 Gard, A.L., Lenz, P.H., Shaw, J.R., Christie, A.E., 2009. Identification of putative peptide 898 paracrines/hormones in the water flea Daphnia pulex (Crustacea; Branchiopoda; Cladocera) 899 using transcriptomics and immunohistochemistry. Gen. Comp. Endocrinol. 160, 271-287.

900

901 Glazer, L., Tom, M., Weil, S., Roth, Z., Khalaila, I., Mittelman, B., Sagi, A., 2013. Hemocyanin 902 with phenoloxidase activity in the chitin matrix of the crayfish gastrolith. J. Exp. Biol. 216, 903 1898-1904.

904

905 Hansen, K.K., Hauser, F., Williamson, M., Weber, S.B., Grimmelikhuijzen, C.J., 2011. The 906 Drosophila genes CG14593 and CG30106 code for G-protein-coupled receptors specifically 907 activated by the neuropeptides CCHamide-1 and CCHamide-2. Biochem. Biophys. Res.

908 Commun. 404, 184-189.

909 
910 Hansen, K.K., Stafflinger, E., Schneider, M., Hauser, F., Cazzamali, G., Williamson, M.,

911 Kollmann, M., Schachtner, J., Grimmelikhuijzen, C.J., 2010. Discovery of a novel insect

912 neuropeptide signaling system closely related to the insect adipokinetic hormone and corazonin

913 hormonal systems. J. Biol. Chem. 285, 10736-10747.

914

915 Hooper, S.L., DiCaprio, R.A., 2004. Crustacean motor pattern generator networks.

916 Neurosignals 13, 50-69.

917

918 Hui, L., D'Andrea, B.T., Jia, C., Liang, Z., Christie, A.E., Li, L., 2013. Mass spectrometric

919 characterization of the neuropeptidome of the ghost crab Ocypode ceratophthalma (Brachyura,

920 Ocypodidae). Gen. Comp. Endocrinol. 184, 22-34.

921

922 Huner, J.V., 1994. Freshwater crayfish aquaculture in North America, Europe, and Australia:

923 families Astacidae, Cambaridae, and Parastacidae. Food Products Press.

924

925 Ida, T., Takahashi, T., Tominaga, H., Sato, T., Sano, H., Kume, K., Ozaki, M., Hiraguchi, T.,

926 Shiotani, H., Terajima, S., Nakamura, Y., Mori, K., Yoshida, M., Kato, J., Murakami, N.,

927 Miyazato, M., Kangawa, K., Kojima, M., 2012. Isolation of the bioactive peptides CCHamide-1

928 and CCHamide-2 from Drosophila and their putative role in appetite regulation as ligands for G

929 protein-coupled receptors. Front. Endocrinol. (Lausanne). 3, 177.

930

931 Jia, C., Lietz, C.B., Yu, Q., Li, L., 2014. Site-specific characterization of (D)-amino acid

932 containing peptide epimers by ion mobility spectrometry. Anal. Chem. 86, 2972-2981. 
934 Jiang, X., Chen, R., Wang, J., Metzler, A., Tlusty, M., Li, L., 2012. Mass spectral charting of 935 neuropeptidomic expression in the stomatogastric ganglion at multiple developmental stages of 936 the lobster Homarus americanus. ACS Chem. Neurosci. 3, 439-450.

938 Katoh, K., Standley, D.M., 2013. MAFFT multiple sequence alignment software version 7:

939 improvements in performance and usability. Mol. Biol. Evol. 30, 772-780.

941 Klose, K., Cooper, S.D., 2013. Complex impacts of an invasive omnivore and native consumers

942 on stream communities in California and Hawaii. Oecologia 171, 945-960.

944 Leksrisawat, B., Cooper, A.S., Gilberts, A.B., Cooper, R.L., 2010. Muscle receptor organs in the 945 crayfish abdomen: a student laboratory exercise in proprioception. J. Vis. Exp. 45.

947 Li, L., Kelley, W.P., Billimoria, C.P., Christie, A.E., Pulver, S.R., Sweedler, J.V., Marder, E., 948 2003. Mass spectrometric investigation of the neuropeptide complement and release in the 949 pericardial organs of the crab, Cancer borealis. J. Neurochem. 87, 642-656.

951 Li, L., Pulver, S.R., Kelley, W.P., Thirumalai, V., Sweedler, J.V., Marder, E., 2002. Orcokinin 952 peptides in developing and adult crustacean stomatogastric nervous systems and pericardial 953 organs. J. Comp. Neurol. 444, 227-244. 
955 Li, S., Torre-Muruzabal, T., Søgaard, K.C., Ren, G.R., Hauser, F., Engelsen, S.M., Pødenphanth,

956 M.D., Desjardins, A., Grimmelikhuijzen, C.J., 2013. Expression patterns of the Drosophila

957 neuropeptide CCHamide-2 and its receptor may suggest hormonal signaling from the gut to the 958 brain. PLoS One 8, e76131.

959

960 Ma, M., Bors, E.K., Dickinson, E.S., Kwiatkowski, M.A., Sousa, G.L., Henry, R.P., Smith, 961 C.M., Towle, D.W., Christie, A.E., Li, L., 2009b. Characterization of the Carcinus maenas 962 neuropeptidome by mass spectrometry and functional genomics. Gen. Comp. Endocrinol. 161, $963 \quad 320-334$.

964

965 Ma, M., Chen, R., Sousa, G.L., Bors, E.K., Kwiatkowski, M.A., Goiney, C.C., Goy, M.F., 966 Christie, A.E., Li, L., 2008. Mass spectral characterization of peptide transmitters/hormones in 967 the nervous system and neuroendocrine organs of the American lobster Homarus americanus. 968 Gen. Comp. Endocrinol. 156, 395-409.

969

970 Ma, M., Gard, A.L., Xiang, F., Wang, J., Davoodian, N., Lenz, P.H., Malecha, S.R., Christie, 971 A.E., Li, L., 2010. Combining in silico transcriptome mining and biological mass spectrometry 972 for neuropeptide discovery in the Pacific white shrimp Litopenaeus vannamei. Peptides 31, 27$973 \quad 43$.

974

975 Ma, M., Szabo, T.M., Jia, C., Marder, E., Li, L., 2009a. Mass spectrometric characterization and 976 physiological actions of novel crustacean C-type allatostatins. Peptides 30, 1660-1668. 977 
978 Manfrin, C., Tom, M., De Moro, G., Gerdol, M., Giulianini, P.G., Pallavicini, A., 2015. The

979 eyestalk transcriptome of red swamp crayfish Procambarus clarkii. Gene 557, 28-34.

980

981 Manfrin, C., Tom, M., De Moro, G., Gerdol, M., Guarnaccia, C., Mosco, A., Pallavicini, A.,

982 Giulianini, P.G., 2013. Application of D-crustacean hyperglycemic hormone induces peptidases

983 transcription and suppresses glycolysis-related transcripts in the hepatopancreas of the crayfish

984 Pontastacus leptodactylus - results of a transcriptomic study. PLoS One 8, e65176.

985

986 Marco, H.G., Anders, L., Gäde, G., 2014. cDNA cloning and transcript distribution of two novel

987 members of the neuroparsin peptide family in a hemipteran insect (Nezara viridula) and a

988 decapod crustacean (Jasus lalandii). Peptides 53, 97-105.

989

990 Marder, E., Bucher, D., 2007. Understanding circuit dynamics using the stomatogastric nervous

991 system of lobsters and crabs. Annu. Rev. Physiol. 69, 291-316.

992

993 Martínez-Pérez, F., Durán-Gutiérrez, D., Delaye, L., Becerra, A., Aguilar, G., Zinker, S., 2007.

994 Loss of DNA: a plausible molecular level explanation for crustacean neuropeptide gene

995 evolution. Peptides 28, 76-82.

996

997 Matsuzaki, S.S., Usio, N., Takamura, N., Washitani, I., 2009. Contrasting impacts of invasive

998 engineers on freshwater ecosystems: an experiment and meta-analysis. Oecologia 158, 673-686.

999 
1000 Mesce, K.A., Fahrbach, S.E., 2002. Integration of endocrine signals that regulate insect ecdysis.

1001 Front. Neuroendocrinol. 23, 179-199.

1002

1003 Monigatti, F., Gasteiger, E., Bairoch, A., Jung, E., 2002. The Sulfinator: predicting tyrosine 1004 sulfation sites in protein sequences. Bioinformatics 18, 769-770.

1005

1006 Patel, H., Orchard, I., Veenstra, J.A., Lange, A.B., 2014. The distribution and physiological

1007 effects of three evolutionarily and sequence-related neuropeptides in Rhodnius prolixus:

1008 Adipokinetic hormone, corazonin and adipokinetic hormone/corazonin-related peptide. Gen.

1009 Comp. Endocrinol. 195, 1-8.

1010

1011 Petersen, T.N., Brunak, S., von Heijne, G., Nielsen, H., 2011. SignalP 4.0: discriminating signal

1012 peptides from transmembrane regions. Nat. Methods 8,785-786.

1013

1014 Robinson, M.M., Martin, J.M., Atwood, H.L., Cooper, R.L., 2011. Modeling biological

1015 membranes with circuit boards and measuring electrical signals in axons: student laboratory

1016 exercises. J. Vis. Exp. 47.

1017

1018 Selverston, A.I., 2005. A neural infrastructure for rhythmic motor patterns. Cell. Mol.

1019 Neurobiol. 25, 223-244.

1020 
1021 Sharp, J.H., Wilcockson, D.C., Webster, S.G., 2010. Identification and expression of mRNAs

1022 encoding bursicon in the plesiomorphic central nervous system of Homarus gammarus. Gen.

1023 Comp. Endocrinol. 169, 65-74.

1024

1025 Skiebe, P., 2001. Neuropeptides are ubiquitous chemical mediators: Using the stomatogastric 1026 nervous system as a model system. J. Exp. Biol. 204, 2035-2048.

1027

1028 Skiebe, P., Dreger, M., Börner, J., Meseke, M., Weckwerth, W., 2003. Immunocytochemical

1029 and molecular data guide peptide identification by mass spectrometry: orcokinin and

1030 orcomyotropin-related peptides in the stomatogastric nervous system of several crustacean

1031 species. Cell. Mol. Biol. (Noisy-le-grand). 49, 851-871.

1032

1033 Skiebe, P., Dreger, M., Meseke, M., Evers, J.F., Hucho, F., 2002. Identification of orcokinins in

1034 single neurons in the stomatogastric nervous system of the crayfish, Cherax destructor. J. Comp.

1035 Neurol. 444, 245-259.

1036

1037 Stafflinger, E., Hansen, K.K., Hauser, F., Schneider, M., Cazzamali, G., Williamson, M.,

1038 Grimmelikhuijzen, C.J., 2008. Cloning and identification of an oxytocin/vasopressin-like

1039 receptor and its ligand from insects. Proc. Natl. Acad. Sci. USA. 105, 3262-3267.

1040

1041 Stemmler, E.A., Bruns, E.A., Cashman, C.R., Dickinson, P.S., Christie, A.E., 2010. Molecular

1042 and mass spectral identification of the broadly conserved decapod crustacean neuropeptide 
1043 pQIRYHQCYFNPISCF: the first PISCF-allatostatin (Manduca sexta- or C-type allatostatin)

1044 from a non-insect. Gen. Comp. Endocrinol. 165, 1-10.

1045

1046 Stemmler, E.A., Bruns, E.A., Gardner, N.P., Dickinson, P.S., Christie, A.E., 2007b. Mass

1047 spectrometric identification of pEGFYSQRYamide: a crustacean peptide hormone possessing a

1048 vertebrate neuropeptide Y (NPY)-like carboxy-terminus. Gen. Comp. Endocrinol. 152, 1-7.

1050 Stemmler, E.A., Cashman, C.R., Messinger, D.I., Gardner, N.P., Dickinson, P.S., Christie, A.E., 1051 2007a. High-mass-resolution direct-tissue MALDI-FTMS reveals broad conservation of three 1052 neuropeptides (APSGFLGMRamide, GYRKPPFNGSIFamide and pQDLDHVFLRFamide) 1053 across members of seven decapod crustaean infraorders. Peptides 28, 2104-2115.

1055 Stemmler, E.A., Gardner, N.P., Guiney, M.E., Bruns, E.A., Dickinson, P.S., 2006. The detection 1056 of red pigment-concentrating hormone (RPCH) in crustacean eyestalk tissues using matrix1057 assisted laser desorption/ionization-Fourier transform mass spectrometry: $[\mathrm{M}+\mathrm{Na}]+$ ion 1058 formation in dried droplet tissue preparations. J. Mass. Spectrom. 41, 295-311.

1060 Stemmler, E.A., Provencher, H.L., Guiney, M.E., Gardner, N.P., Dickinson, P.S., 2005. Matrix1061 assisted laser desorption/ionization fourier transform mass spectrometry for the identification of 1062 orcokinin neuropeptides in crustaceans using metastable decay and sustained off-resonance 1063 irradiation. Anal. Chem. 77, 3594-3606.

1064 
1065 Stepanyan, R., Day, K., Urban, J., Hardin, D.L., Shetty, R.S., Derby, C.D., Ache, B.W.,

1066 McClintock, T.S., 2006. Gene expression and specificity in the mature zone of the lobster

1067 olfactory organ. Physiol. Genomics 25, 224-233.

1068

1069 Stevens, J.S., Cashman, C.R., Smith, C.M., Beale, K.M., Towle, D.W., Christie, A.E.,

1070 Dickinson, P.S., 2009. The peptide hormone pQDLDHVFLRFamide (crustacean

1071 myosuppressin) modulates the Homarus americanus cardiac neuromuscular system at multiple

1072 sites. J. Exp. Biol. 212, 3961-3976.

1073

1074 Tom, M., Manfrin, C., Chung, S.J., Sagi, A., Gerdol, M., De Moro, G., Pallavicini, A.,

1075 Giulianini, P.G., 2014. Expression of cytoskeletal and molt-related genes is temporally

1076 scheduled in the hypodermis of the crayfish Procambarus clarkii during premolt. J. Exp. Biol.

$1077 \quad 217,4193-4202$.

1078

1079 Tom, M., Manfrin, C., Giulianini, P.G., Pallavicini, A., 2013. Crustacean oxi-reductases protein

1080 sequences derived from a functional genomic project potentially involved in ecdysteroid

1081 hormones metabolism - a starting point for function examination. Gen. Comp. Endocrinol. 194,

$1082 \quad 71-80$.

1083

1084 Toullec, J.Y., Corre, E., Bernay, B., Thorne, M.A., Cascella, K., Ollivaux, C., Henry, J., Clark,

1085 M.S., 2013. Transcriptome and peptidome characterisation of the main neuropeptides and

1086 peptidic hormones of a euphausiid: the Ice Krill, Euphausia crystallorophias. PLoS One. 8, 1087 e71609. 
1089 Towle, D.W., Smith, C.M., 2006. Gene discovery in Carcinus maenas and Homarus americanus

1090 via expressed sequence tags. Integr. Comp. Biol. 46, 912-918.

1091

1092 Truman, J.W., 2005. Hormonal control of insect ecdysis: endocrine cascades for coordinating

1093 behavior with physiology. Vitam. Horm. 73, 1-30.

1094

1095 Veenstra, J.A., 2000. Mono- and dibasic proteolytic cleavage sites in insect neuroendocrine

1096 peptide precursors. Arch. Insect. Biochem. Physiol. 43, 49-63.

1097

1098 Ventura, T., Cummins, S.F., Fitzgibbon, Q., Battaglene, S., Elizur, A., 2014. Analysis of the

1099 central nervous system transcriptome of the eastern rock lobster Sagmariasus verreauxi reveals

1100 its putative neuropeptidome. PLoS One 9, e97323.

1101

1102 Yan, X.C., Chen, Z.F., Sun, J., Matsumura, K., Wu, R.S., Qian, P.Y., 2012. Transcriptomic

1103 analysis of neuropeptides and peptide hormones in the barnacle Balanus amphitrite: evidence of 1104 roles in larval settlement. PLoS One 7, e46513.

1105

1106 Yang, S.P., He, J.G., Sun, C.B., Chan, S.F., 2014. Characterization of the shrimp neuroparsin

1107 (MeNPLP): RNAi silencing resulted in inhibition of vitellogenesis. FEBS Open Bio. 4, 9761108986

1109 
1110 Yasuda, A., Yasuda-Kamatani, Y., Nozaki, M., Nakajima, T., 2004. Identification of

1111 GYRKPPFNGSIFamide (crustacean-SIFamide) in the crayfish Procambarus clarkii by

1112 topological mass spectrometry analysis. Gen. Comp. Endocrinol. 135, 391-400.

1113

1114 Yasuda-Kamatani, Y., Yasuda, A., 2004. APSGFLGMRamide is a unique tachykinin-related

1115 peptide in crustaceans. Eur. J. Biochem. 271, 1546-1556.

1116

1117 Yasuda-Kamatani, Y., Yasuda, A., 2006. Characteristic expression patterns of allatostatin-like

1118 peptide, FMRFamide-related peptide, orcokinin, tachykinin-related peptide, and SIFamide in the

1119 olfactory system of crayfish Procambarus clarkii. J. Comp. Neurol. 496, 135-147.

1120

1121 Yue, G.H., Li, J.L., Wang, C.M., Xia, J.H., Wang, G.L., Feng, J.B., 2010. High prevalence of

1122 multiple paternity in the invasive crayfish species, Procambarus clarkii. Int. J. Biol. Sci. 6, 107-

1123115.

1124

1125 Zitnan, D., Kim, Y.J., Zitnanová, I., Roller, L., Adams, M.E., 2007. Complex steroid-peptide-

1126 receptor cascade controls insect ecdysis. Gen. Comp. Endocrinol. 153, 88-96.

\section{Figure legends}

1129 Figure 1. Three examples of the in silico workflow used for the prediction of putative mature

1130 peptide structures. (A) Predicted processing scheme for Procambarus clarkii (Procl)-prepro-

1131 adipokinetic hormone-corazonin-like peptide (ACP). The structure of the putative mature ACP

1132 isoform is shown in red, with those of four putative mature linker/precursor-related peptides 
1133 shown in blue. In this panel, the pyroglutamic acid residue present in the putative mature ACP is

1134 indicated by "pQ". (B) Predicted processing scheme for Procl-prepro-CCHamide I. The

1135 structure of the putative mature CCHamide isoform is shown in red, with those of three putative

1136 mature linker/precursor-related peptides shown in blue. In this panel, the inverted red bracket

1137 indicates a disulfide bond between the two cysteine residues in the putative mature CCHamide.

1138 (C) Predicted processing scheme for the extant portion of Procl-prepro-sulfakinin. The

1139 structures of two putative mature sulfakinin isoforms are shown in red, with those of four

1140 putative mature linker/precursor-related peptides (one partial) shown in blue. In this panel, the

1141 presence of sulfated tyrosine residues in the two putative mature sulfakinins is indicated by

1142 "Y $\mathrm{S}_{(\mathrm{SO} 3 \mathrm{H})}$ ", while the presence of pyroglutamic acid in one sulfakinin is indicated by "pE".

1144 Figure 2. Putative Procambarus clarkii (Procl) pre/preprohormones deduced from transcriptome

1145 shotgun assembly sequence data. (A) Procl-prepro-allatostatin A. (B) The amino (N)-terminal

1146 portion of Procl-prepro-allatostatin B. (C) Procl-prepro-allatostatin C. (D) Procl-pre-bursicon

$1147 \alpha$. (E) The carboxyl (C)-terminal portion of Procl-pre-bursicon $\beta$. (F) The C-terminal portion of

1148 Procl-prepro-CCHamide II. (G1) An internal protein fragment of Procl-prepro-crustacean

1149 hyperglycemic hormone I. (G2) Procl-prepro-crustacean hyperglycemic hormone II. (G3)

1150 Procl-prepro-crustacean hyperglycemic hormone III. (H) Procl-prepro-diuretic hormone 31. (I)

1151 Procl-pre-eclosion hormone. (J1) Procl-prepro-FMRFamide-like peptide I. (J2) The C-terminal

1152 portion of Procl-prepro-FMRFamide-like peptide II. (J3) The C-terminal portion of Procl-

1153 prepro-FMRFamide-like peptide III. (K) The C-terminal portion of Procl-prepro-GSEFLamide.

1154 (L) The N-terminal portion of Procl-prepro-intocin. (M1) The N-terminal portion of Procl-

1155 prepro-leucokinin I. (M2) An internal protein fragment of Procl-prepro-leucokinin II. (N1) The 
1156 C-terminal portion of Procl-pre-neuroparsin I. (N2) Procl-pre-neuroparsin II. (O1) Procl-prepro-

1157 neuropeptide F I. (O2) The N-terminal portion of Procl-prepro-neuropeptide F II. (P) The C-

1158 terminal portion of Procl-prepro-pigment dispersing hormone. (Q) The C-terminal portion of

1159 Procl-prepro-pyrokinin. (R) Procl-prepro-RYamide. (S) Procl-prepro-short neuropeptide F. (T)

1160 Procl-prepro-SIFamide. (U) Procl-prepro-tachykinin-related peptide. In this figure, signal

1161 peptides are shown in gray, while all mono/dibasic cleavage loci are shown in black. For each

1162 sequence, the isoform(s) of the peptide for which the precursor is named is/are shown in red,

1163 with all linker/precursor related peptides shown in blue. The "+" symbol indicate the presence of

1164 additional, unknown, amino acid residues at the $\mathrm{N}$ - and/or C-terminus.

1166 Figure 3. Alignment of selected Procambarus clarkii (Procl) precursors deduced in this study

1167 with previously known preprohormones. (A) Alignment of Procl-prepro-allatostatin A and

1168 BAE45266 (Yasuda-Kamatani and Yasuda, 2006). (B1) Alignment of Procl-prepro-

1169 FMRFamide-like peptide I and BAE06262 (Yasuda-Kamatani and Yasuda, 2006). (B2)

1170 Alignment of Procl-prepro-FMRFamide-like peptide I and BAE06263 (Yasuda-Kamatani and

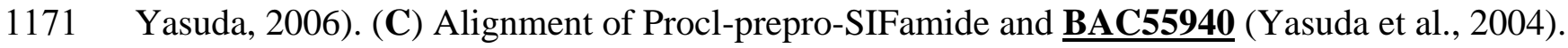

1172 (D) Alignment of Procl-prepro-tachykinin-related peptide and BAC82426 (Yasuda-Kamatani

1173 and Yasuda, 2004). In the line immediately below each sequence grouping, “*” indicates amino

1174 acids that are identically conserved between the two proteins, while "." and "." denote amino

1175 acids that are similar in structure between the two sequences (i.e. conservative amino acid

1176 substitutions). 
1178 Figure 4. Putative Pontastacus leptodactylus (Ponle) pre/preprohormones deduced from

1179 transcriptome shotgun assembly sequence data. (A) An internal protein fragment of Ponle-

1180 prepro-allatostatin A. (B) The carboxyl (C)-terminal portion of Ponle-prepro-allatostatin C. (C)

1181 The amino (N)-terminal portion of Ponle-pre-bursicon $\alpha$. (D) Ponle-prepro-CCHamide. (E1)

1182 Ponle-prepro-crustacean hyperglycemic hormone I. (E2) An internal protein fragment of Ponle-

1183 prepro-crustacean hyperglycemic hormone II. (E3) Ponle-prepro-crustacean hyperglycemic

1184 hormone III. (F) The C-terminal portion of Ponle-prepro-DH31. (G) Ponle-pre-eclosion

1185 hormone. (H) Ponle-prepro-intocin. (I) Ponle-prepro-myosuppressin. (J1) Ponle-pre-

1186 neuroparsin I. (J2) Ponle-pre-neuroparsin II. (J3) The C-terminal portion of Procl-prepro-

1187 FMRFamide-like peptide III. (K) The C-terminal portion of Ponle-prepro-red pigment

1188 concentrating hormone. (L) Procl-prepro-short neuropeptide F. (M) An internal protein

1189 fragment of Ponle-prepro-tachykinin-related peptide. In this figure, signal peptides are shown in

1190 gray, while all mono/dibasic cleavage loci are shown in black. For each sequence, the isoform(s)

1191 of the peptide for which the precursor is named is/are shown in red, with all linker/precursor

1192 related peptides shown in blue. The "+" symbol indicate the presence of additional, unknown,

1193 amino acid residues at the $\mathrm{N}$ - and/or C-terminus.

1195 Figure 5. Putative Cherax quadricarinatus (Chequ) prehormones deduced from transcriptome

1196 shotgun assembly sequence data. (A) The carboxyl (C)-terminal portion of Chequ-pre-bursicon

$1197 \beta$. (B) Chequ-pre-neuroparsin. In this figure, signal peptides are shown in gray, with the

1198 isoform of the peptide for which the precursor is named shown in red. In panel A, the "+”

1199 symbol indicate the presence of additional, unknown, amino acid residues at the amino-terminus

1200 of the bursicon $\beta$ precursor. 
1202 Figure 6. Comparisons of crustacean adipokinetic hormone-corazonin-like peptide isoforms and

1203 precursor proteins. (A) Structural comparison between known astacidean isoforms of red

1204 pigment concentrating hormone (RPCH), adipokinetic hormone-corazonin-like peptide (ACP)

1205 and corazonin. Structural features (amino acid residues and carboxyl (C)-terminal amidation)

1206 that are identically conserved between all three peptides are colored red. Amino acids that are

1207 shared by ACP and corazonin, but not RPCH, are colored green. A pair of conserved, but not

1208 identical, amino acids shared by RPCH and ACP, but not corazonin, is colored blue. (B)

1209 Alignment of known crustacean ACP isoforms. Structural features (amino acid residues and C-

1210 terminal amidation) that are identically conserved between all isoforms are colored red, with

1211 conserved, but not identical, amino acids shared by all isoforms highlighted in yellow. (C).

1212 Alignment of a representative insect (Tribolium castaneum [Trica]; Accession No. $\underline{\text { ADF28807 }}$

1213 [Hansen et al., 2010]) and all known crustacean ACP preprohormones. In all protein sequences,

1214 the isoform(s) of ACP (including the C-terminal glycine residue that serves as an amidation

1215 signal) is colored red. In the line immediately below each sequence grouping, “*” indicates

1216 amino acids that are identically conserved between the two proteins, while "." and ":" denote

1217 amino acids that are similar in structure between the two sequences (i.e. conservative amino acid

1218 substitutions). Other abbreviations: Procl, Procambarus clarkii (Astacidea); Spetu,

1219 Speleonectes cf. tulumensis (Remipedia); Tigca, Tigriopus californicus (Copepoda); Eucse,

1220 Eucyclops serrulatus (Copepoda). Other references to sequence data: P. clarkii (this study), $S$.

1221 cf. tulumensis (Christie, 2014a), T. californicus (Christie, 2014b), E. serrulatus (Christie, 2015b). 


\begin{tabular}{|c|c|c|c|c|c|c|c|}
\hline \multirow[b]{2}{*}{ Peptide Family } & \multicolumn{5}{|c|}{ TSA transcript/protein identifications } & \multicolumn{2}{|c|}{ tblasn search statistics } \\
\hline & Species & $\begin{array}{c}\text { Transcript } \\
\text { accession } \\
\text { number }\end{array}$ & $\begin{array}{c}\text { Transcript } \\
\text { length* }\end{array}$ & $\begin{array}{c}\text { Deduced protein } \\
\text { length }\end{array}$ & $\begin{array}{c}\text { Deduced protein } \\
\text { type }^{\ddagger}\end{array}$ & BLAST score & E-value \\
\hline ACP & P. clarkii & GBEV01011002 & 607 & 100 & $\mathrm{~F}$ & 28.5 & 2.9 \\
\hline AST-A & $\begin{array}{l}\text { P. clarkii } \\
\text { P. leptodactylus }\end{array}$ & $\begin{array}{l}\text { GBEV01001712 } \\
\text { GAFS01069035 }\end{array}$ & $\begin{array}{l}3193 \\
282\end{array}$ & $\begin{array}{l}523 \\
93\end{array}$ & $\begin{array}{l}\mathrm{F} \\
\mathrm{I}\end{array}$ & $\begin{array}{l}770 \\
73.6 \\
\end{array}$ & $\begin{array}{l}0.0 \\
2 \mathrm{e}-14\end{array}$ \\
\hline AST-B & P. clarkii & GBEV01040422 & 504 & 92 & $\mathrm{~N}$ & 67.8 & $2 \mathrm{e}-12$ \\
\hline AST-C & $\begin{array}{l}\text { P. clarkii } \\
\text { P. leptodactylus }\end{array}$ & $\begin{array}{l}\text { GBEV01001327 } \\
\text { GAFY01028258 }\end{array}$ & $\begin{array}{l}1778 \\
272 \\
\end{array}$ & $\begin{array}{l}164 \\
72 \\
\end{array}$ & $\begin{array}{l}\mathrm{F} \\
\mathrm{C}\end{array}$ & $\begin{array}{l}30.4 \\
115 \\
\end{array}$ & $\begin{array}{l}1.1 \\
8 \mathrm{e}-33\end{array}$ \\
\hline Allatotropin & & & & & & & \\
\hline Bursicon $\alpha$ & $\begin{array}{l}\text { P. clarkii } \\
\text { P. leptodactylus }\end{array}$ & $\begin{array}{l}\text { GBEV01070554 } \\
\text { GAFS01049726 }\end{array}$ & $\begin{array}{l}1792 \\
235\end{array}$ & $\begin{array}{l}142 \\
41\end{array}$ & $\begin{array}{l}\mathrm{F} \\
\mathrm{N}\end{array}$ & $\begin{array}{l}258 \\
57.0\end{array}$ & $\begin{array}{l}4 e-82 \\
2 e-10\end{array}$ \\
\hline Bursicon $\beta$ & $\begin{array}{l}\text { P. clarkii } \\
\text { C. quadricarinatus }\end{array}$ & $\begin{array}{l}\text { GBEV01054566 } \\
\text { GADE01008158 }\end{array}$ & $\begin{array}{l}310 \\
478 \\
\end{array}$ & $\begin{array}{l}89 \\
48 \\
\end{array}$ & $\begin{array}{l}\mathrm{C} \\
\mathrm{C}\end{array}$ & $\begin{array}{l}171 \\
87.8\end{array}$ & $\begin{array}{l}8 \mathrm{e}-54 \\
5 \mathrm{e}-21\end{array}$ \\
\hline CCHamide & $\begin{array}{l}\text { P. clarkii } \\
\text { P. leptodactylus }\end{array}$ & $\begin{array}{l}\text { GBEV01004199 } \\
\text { GBEV01015793 } \\
\text { GAFS01018472 }\end{array}$ & $\begin{array}{l}2529 \\
5007 \\
\\
1270 \\
\end{array}$ & $\begin{array}{l}118 \\
204 \\
246\end{array}$ & $\begin{array}{l}\mathrm{F} \\
\mathrm{C} \\
\mathrm{F}\end{array}$ & $\begin{array}{l}83.6 \\
31.6 \\
\\
32.3 \\
\end{array}$ & $\begin{array}{l}\mathrm{e}-18 \\
0.82 \\
\\
0.41\end{array}$ \\
\hline Corazonin & & & & & & & \\
\hline CCAP & & & & & & & \\
\hline $\mathrm{CHH} / \mathrm{ITP}$ & $\begin{array}{l}\text { P. clarkii } \\
\text { P. leptodactylus }\end{array}$ & $\begin{array}{l}\text { GBEV01000359 } \\
\text { GBEV01014441 } \\
\text { GBEV01008025 } \\
\\
\text { GAFS01024727 } \\
\text { GAFS01049968 } \\
\text { GAFS01042936 }\end{array}$ & $\begin{array}{l}257 \\
2949 \\
2300 \\
\\
802 \\
228 \\
913 \\
\end{array}$ & $\begin{array}{l}85 \\
139 \\
120 \\
\\
137 \\
76 \\
140 \\
\end{array}$ & $\begin{array}{l}\mathrm{I} \\
\mathrm{F} \\
\mathrm{F} \\
\mathrm{F} \\
\mathrm{I} \\
\mathrm{F} \\
\end{array}$ & $\begin{array}{l}115 \\
83.2 \\
63.9 \\
\\
173 \\
140 \\
81.6 \\
\end{array}$ & $\begin{array}{l}\text { ee-32 } \\
8 \mathrm{e}-18 \\
2 \mathrm{e}-11 \\
\\
6 \mathrm{e}-53 \\
1 \mathrm{e}-42 \\
2 \mathrm{e}-18 \\
\end{array}$ \\
\hline DENamide & & & & & & & \\
\hline DH31 & $\begin{array}{l}\text { P. clarkii } \\
\text { P. leptodactylus }\end{array}$ & $\begin{array}{l}\text { GBEV01003269 } \\
\text { GAFS01038688 }\end{array}$ & $\begin{array}{l}1863 \\
268 \\
\end{array}$ & $\begin{array}{l}136 \\
66 \\
\end{array}$ & $\begin{array}{l}\mathrm{F} \\
\mathrm{C}\end{array}$ & $\begin{array}{l}169 \\
79.3 \\
\end{array}$ & $\begin{array}{l}5 e-49 \\
1 e-18 \\
\end{array}$ \\
\hline DH44 & & & & & & & \\
\hline DXXRLamide & & & & & & & \\
\hline
\end{tabular}




\begin{tabular}{|c|c|c|c|c|c|c|c|}
\hline \multicolumn{8}{|l|}{ ETH } \\
\hline \multirow[t]{2}{*}{$\mathrm{EH}$} & P. clarkii & GBEV01101142 & 527 & 85 & $\mathrm{~F}$ & 54.3 & $2 \mathrm{e}-09$ \\
\hline & P. leptodactylus & GAFS01039705 & 1028 & 88 & $\mathrm{~F}$ & 57.0 & $1 \mathrm{e}-09$ \\
\hline \multirow[t]{4}{*}{ FLP } & P. clarkii & GBEV01020536 & 2003 & 384 & $\mathrm{~F}$ & 311 & $4 e-99$ \\
\hline & & GBEV01106719 & 381 & 29 & $\mathrm{C}$ & 38.1 & 0.012 \\
\hline & & GBEV01105142 & 548 & 166 & $\mathrm{C}$ & 117 & $7 e-38$ \\
\hline & & GBEV01189645 & 1045 & 158 & $\mathrm{C}$ & 132 & $4 e-34$ \\
\hline \multicolumn{8}{|l|}{ FXGGXamide } \\
\hline GSEFLamide & P. clarkii & GBEV01013249 & 5907 & 136 & $\mathrm{C}$ & 143 & $2 \mathrm{e}-37$ \\
\hline \multicolumn{8}{|l|}{ ILP } \\
\hline \multirow[t]{2}{*}{ Intocin } & P. clarkii & GBEV01109169 & 281 & 77 & $\mathrm{~N}$ & 89.7 & $2 \mathrm{e}-22$ \\
\hline & P. leptodactylus & GAFS01000331 & 737 & 153 & $\mathrm{~F}$ & 172 & $1 e-52$ \\
\hline \multirow[t]{3}{*}{ Leucokinin } & P. clarkii & GBEV01013648 & 1138 & 356 & $\mathrm{~N}$ & 34.3 & 0.37 \\
\hline & & GBEV01006537 & 466 & 155 & $\mathrm{I}$ & 32.7 & 0.75 \\
\hline & & GBEV01006538 & 463 & 154 & I & 33.9 & 0.30 \\
\hline Myosuppressin & P. leptodactylus & GAFS01019764 & 732 & 99 & $\mathrm{~F}$ & 127 & $6 e-36$ \\
\hline \multirow[t]{6}{*}{ Neuroparsin } & P. clarkii & GBEV01003881 & 1062 & 95 & $\mathrm{C}$ & 132 & $3 e-37$ \\
\hline & & GBEV01000414 & 5114 & 101 & $\mathrm{~F}$ & 69.3 & $2 \mathrm{e}-13$ \\
\hline & P. leptodactylus & GAFS01000216 & 1154 & 107 & $\mathrm{~F}$ & 137 & $2 \mathrm{e}-38$ \\
\hline & & GAFY01019447 & 2524 & 101 & $\mathrm{~F}$ & 70.9 & $4 \mathrm{e}-14$ \\
\hline & & GAFS01005142 & 2584 & 101 & $\mathrm{~F}$ & 70.9 & $4 \mathrm{e}-14$ \\
\hline & C. quadricarinatus & GADE01014957 & 484 & 101 & $\mathrm{~F}$ & 64.7 & $4 e-13$ \\
\hline \multirow[t]{2}{*}{ NPF } & P. clarkii & GBEV01005906 & 1178 & 104 & $\mathrm{~F}$ & 34.3 & 0.036 \\
\hline & & GBEV01020719 & 425 & 56 & $\mathrm{~N}$ & 55.8 & $3 e-10$ \\
\hline \multicolumn{8}{|l|}{ Orcokinin } \\
\hline PDH & P. clarkii & GBEV01236728 & 230 & 51 & $\mathrm{C}$ & 26.6 & 4.8 \\
\hline \multicolumn{8}{|l|}{ Proctolin } \\
\hline Pyrokinin & P. clarkii & GBEV01049409 & 253 & 75 & $\mathrm{C}$ & 63.2 & $9 \mathrm{e}-13$ \\
\hline $\mathrm{RPCH}$ & P. leptodactylus & GAFS01040704 & 563 & 95 & $\mathrm{C}$ & 95.1 & $2 \mathrm{e}-24$ \\
\hline RYamide & P. clarkii & GBEV01010112 & 2521 & 134 & $\mathrm{~F}$ & 95.5 & $1 \mathrm{e}-22$ \\
\hline \multirow[t]{2}{*}{ sNPF } & P. clarkii & GBEV01004780 & 4804 & 129 & $\mathrm{~F}$ & 32.0 & 0.53 \\
\hline & P. leptodactylus & GAFS01014236 & 1058 & 128 & $\mathrm{~F}$ & 32.3 & 0.34 \\
\hline SIFamide & P. clarkii & GBEV01000221 & 2358 & 76 & $\mathrm{~F}$ & 92.4 & $6 e-22$ \\
\hline Sulfakinin & P. clarkii & GBEV01027368 & 475 & 103 & $\mathrm{C}$ & 148 & $6 e-45$ \\
\hline
\end{tabular}




\begin{tabular}{|c|c|c|c|c|c|c|c|}
\hline TRP & & & & & & & \\
\hline \multicolumn{8}{|c|}{ 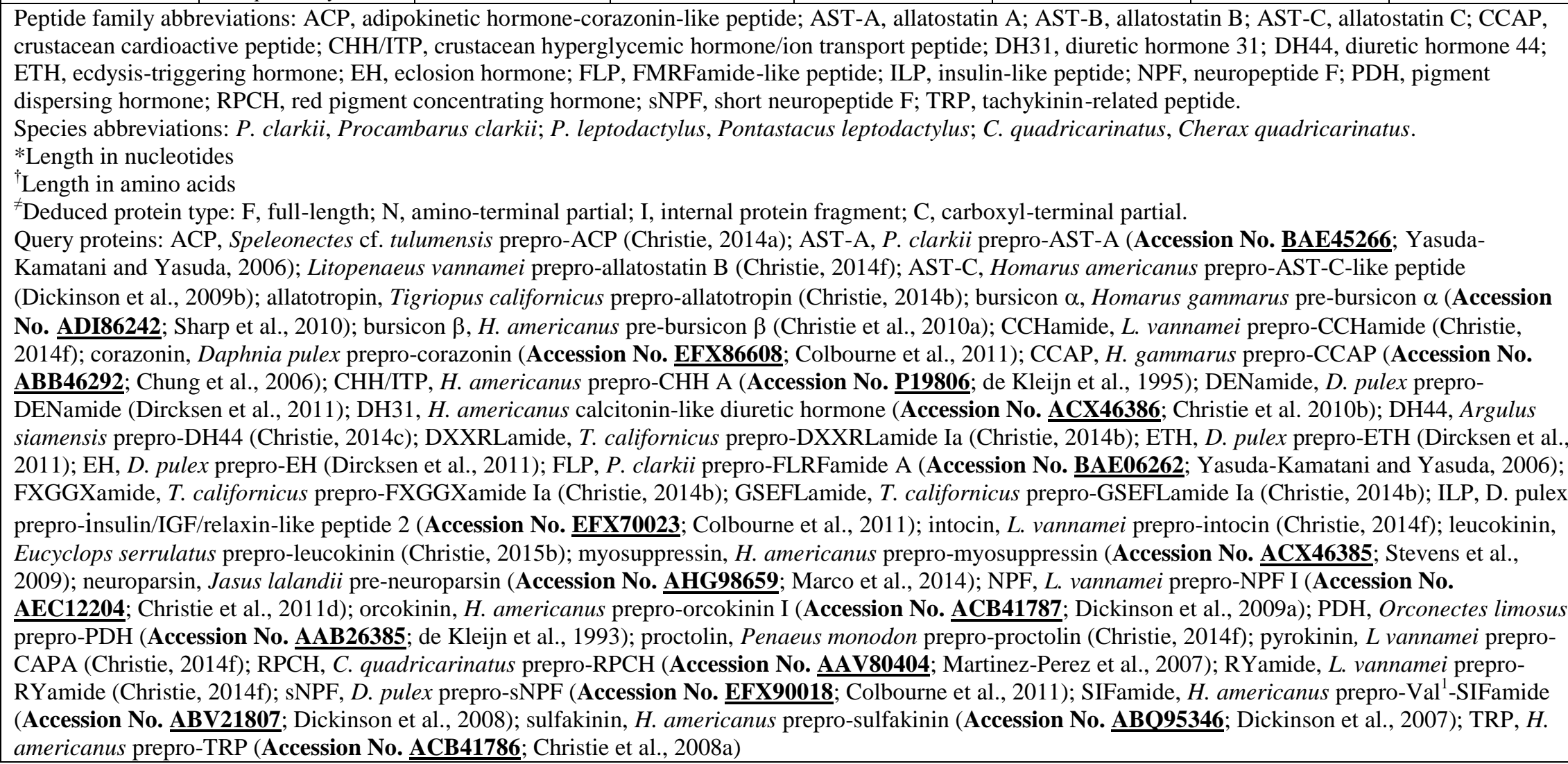 } \\
\hline
\end{tabular}




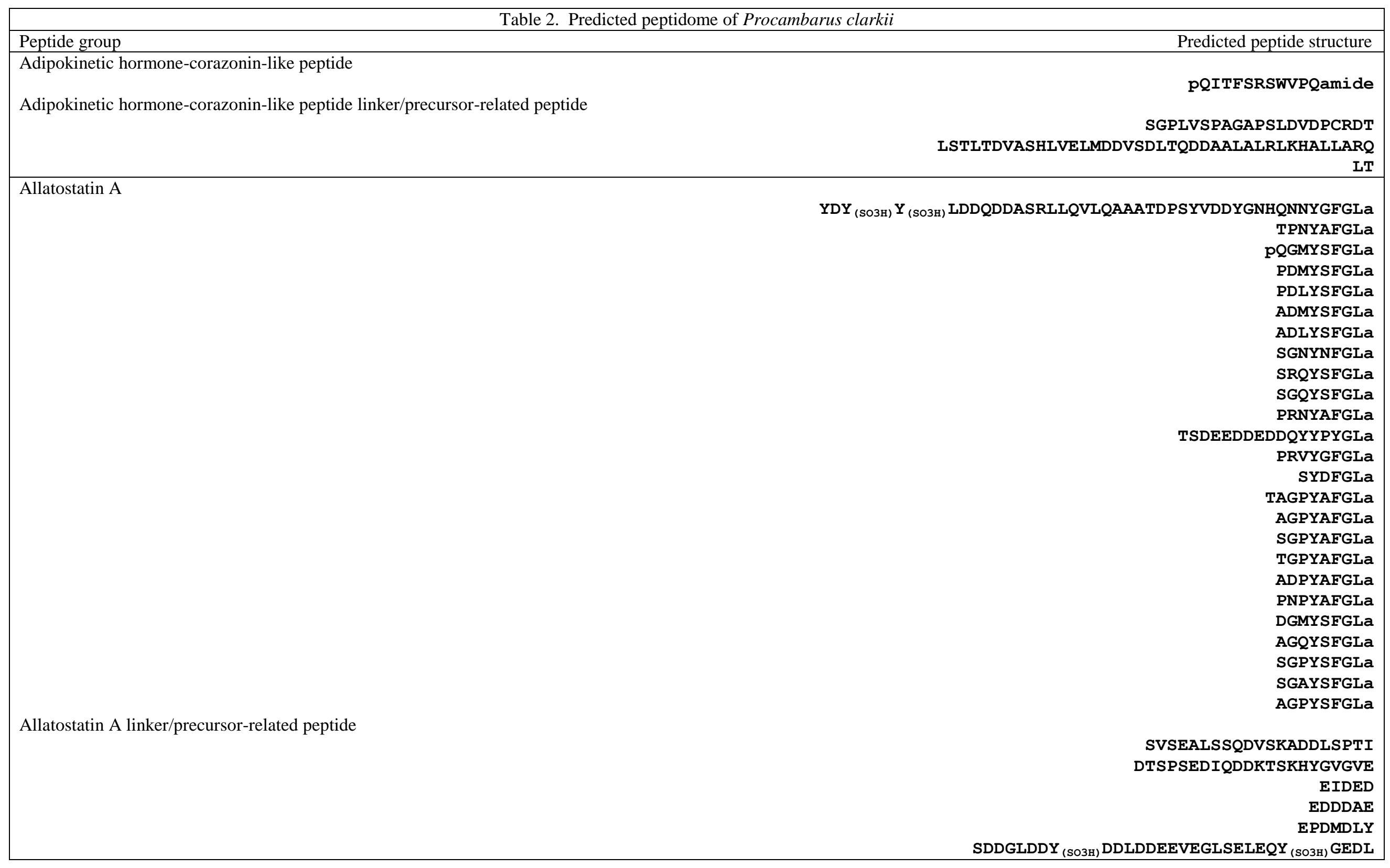




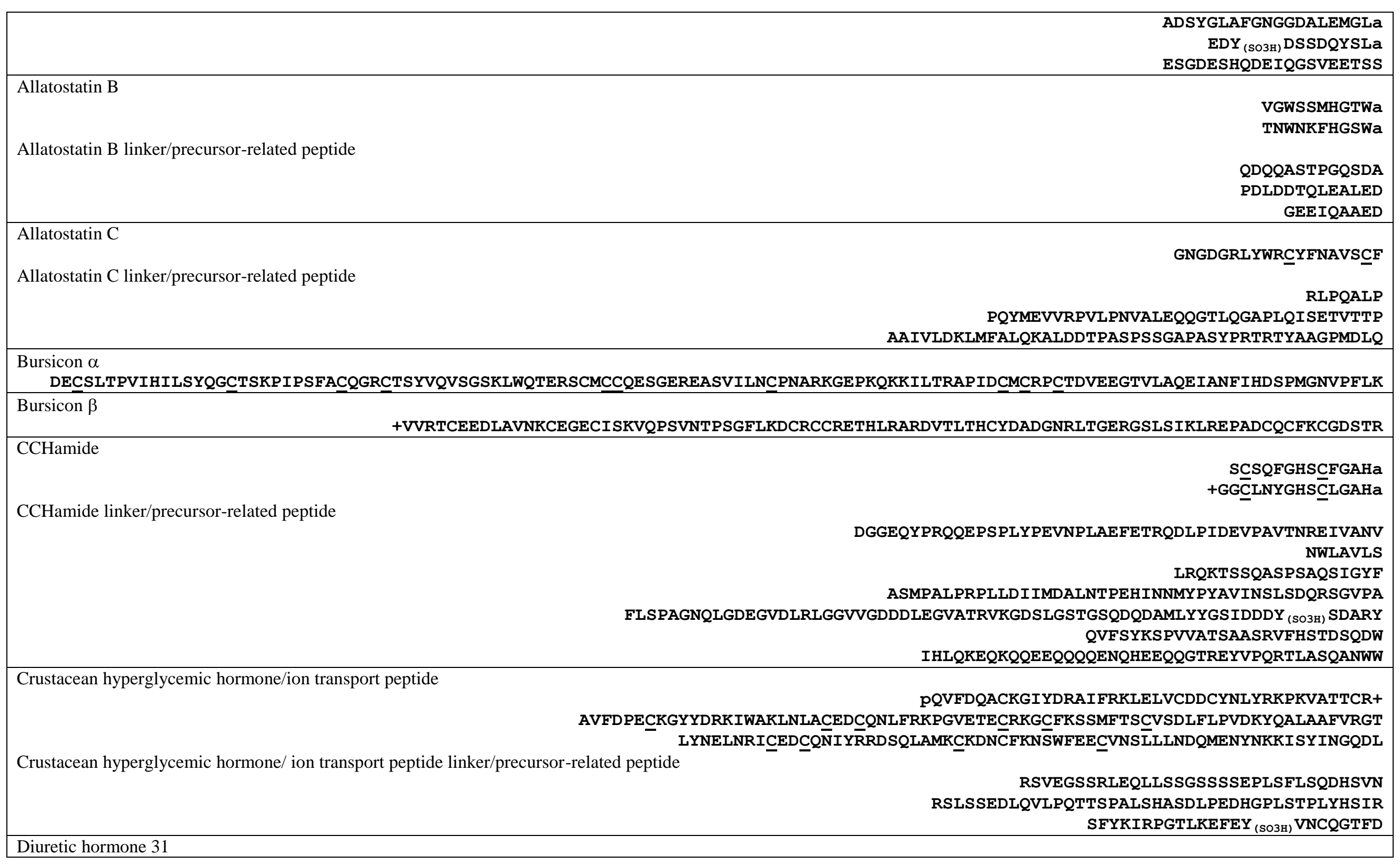




\begin{tabular}{|c|c|}
\hline \multirow{5}{*}{ Diuretic hormone 31 linker/precursor-related peptide } & GLDLGLGRGYSGSQAAKHLMGLAAANFAGGPa \\
\hline & ASLNREA \\
\hline & AVVEIDDPDY $_{(\text {(О)H }) \text { VLELLTRLGHSII }}$ \\
\hline & ANELEKFVRSSGSA \\
\hline & SSDDALDHDDNLYAHDQVAELAESS \\
\hline \multicolumn{2}{|l|}{ Eclosion hormone } \\
\hline & AANKVSVCIKNCAQCKVMYHDHFKGGLCADFCVQSEGRFIPDCARPQTLIPFFLQRLE \\
\hline \multicolumn{2}{|l|}{ FMRFamide-like peptide } \\
\hline & AYSDRNYLRFa \\
\hline & SRNFLRFa \\
\hline & DHSRNFLRFa \\
\hline & SPHKSYRHLVKGNRNFPRFa \\
\hline & GDRNFLRFa \\
\hline & AHDRNFLRFa \\
\hline & DRNFLRFa \\
\hline & APQRNFLRFa \\
\hline & AYSDRNFLRFa \\
\hline & NRNFLRFa \\
\hline & GFSDKNFMRFa \\
\hline & GGHNVLRFa \\
\hline \multicolumn{2}{|l|}{ FMRFamide-like peptide linker/precursor-related peptide } \\
\hline & APVPPVAAALSSPSQGFGSNNSEDDSVAQPE \\
\hline & LLKYFLPGSQAWMDDGGDLYPISQEGS \\
\hline & NDDD \\
\hline & SDLGDY $_{(\mathrm{Sо} о \mathrm{H})}$ DNRDEGGLSDSLD \\
\hline & SDMEDLSLAGGPMDFPAGLLDEVDQEDLPFQE \\
\hline & SVDSQLNALSCDGCDGPKTSVSSTPSPTPVQPVTST \\
\hline & DISTHSIEASNPSGSTSQRM \\
\hline & AVDPTFY $_{(\text {(ОЗ3н) }}$ DYGSMLSY $_{(\text {(ОозH) }}$ SPSSWARGFQPEEEIITVSSEDPQDVN \\
\hline & DRSNEY $_{(\mathrm{SO} \mathrm{H})}$ PPSSPSESSESLVAVSPAEYSRNV \\
\hline & SDVE \\
\hline & SDLGDY $_{(\mathrm{SO} \mathrm{H})}$ HNSDDETLNDSLV \\
\hline & PDMEDMFVAGGPMEFLNSLEGEVVKDDLPLEKQAAYRH \\
\hline & SVTRQLNAQSCDGCDGPKTQETTPHPPLPLRSSQRPLPSMTSLTRSSPQNPGRALLIA \\
\hline & +AALSPPSHDFSFINNREESEGLPEKGVLKYFNPGRQGWVDGAEDYHPFAEDVS \\
\hline & SLDTRSNTLCLVGCDEEPKTQDHTCLPTSFHPTTRVERDIQSPEPGQQTSQ \\
\hline & AASKTFYDFRKTPSYSPSSWARGFQP \\
\hline \multicolumn{2}{|l|}{ GSEFLamide } \\
\hline & AVGSEFLa \\
\hline & AMGSEFLa \\
\hline
\end{tabular}




\begin{tabular}{|c|c|}
\hline GSEFLamide linker/precursor-related peptide & $\begin{array}{r}\text { AMGAEFLa } \\
\text { ATGLEFLNERVMGSELLa } \\
\text { YMGSEFSa } \\
\text { AKASEFE } \\
\text { HYEPAFMHALIYDP }\end{array}$ \\
\hline Intocin & 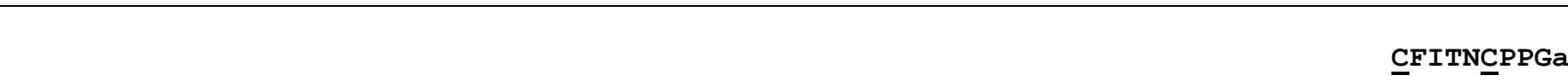 \\
\hline Intocin linker/precursor-related peptide & SGASTQIARSRT $\underline{C} S S \underline{C}$ GPGLRGRCLGPEICCGEEVGCFLLATREA \\
\hline Leucokinin & $\begin{array}{r}\text { PQPFYHWGa } \\
\text { ATFNPWGGKQSDPIHTASLTSDAFNDSPSKGNTFPWGa } \\
\text { GFSAWAa } \\
\text { AFSAWAa } \\
\text { PQAFNAWAa } \\
\text { PQAFSAWAa } \\
\text { HSFSAWAa } \\
\text { HTFSSWAa } \\
\text { PQAFSPWAa } \\
\text { PQAFSSWAa } \\
\text { HAFSSWAa }\end{array}$ \\
\hline Leucokinin linker/precursor-related peptide & 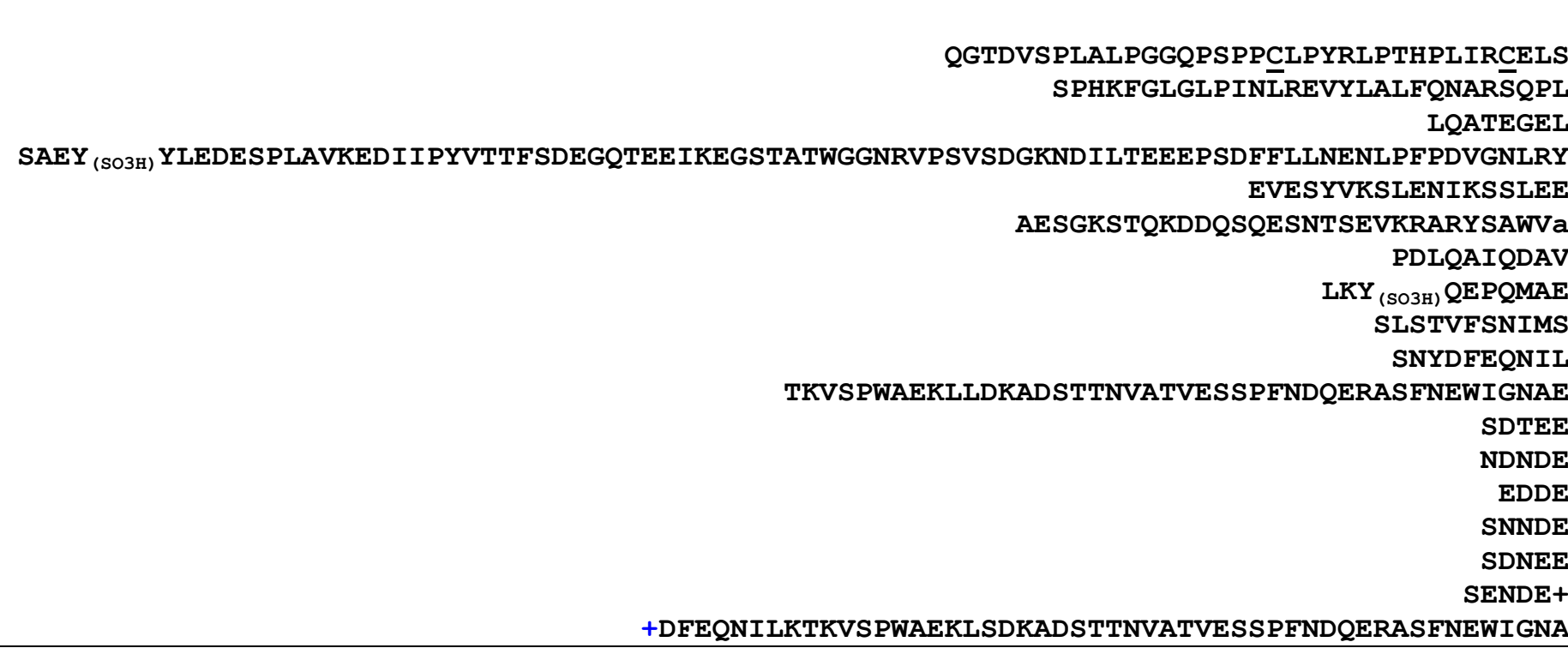 \\
\hline
\end{tabular}




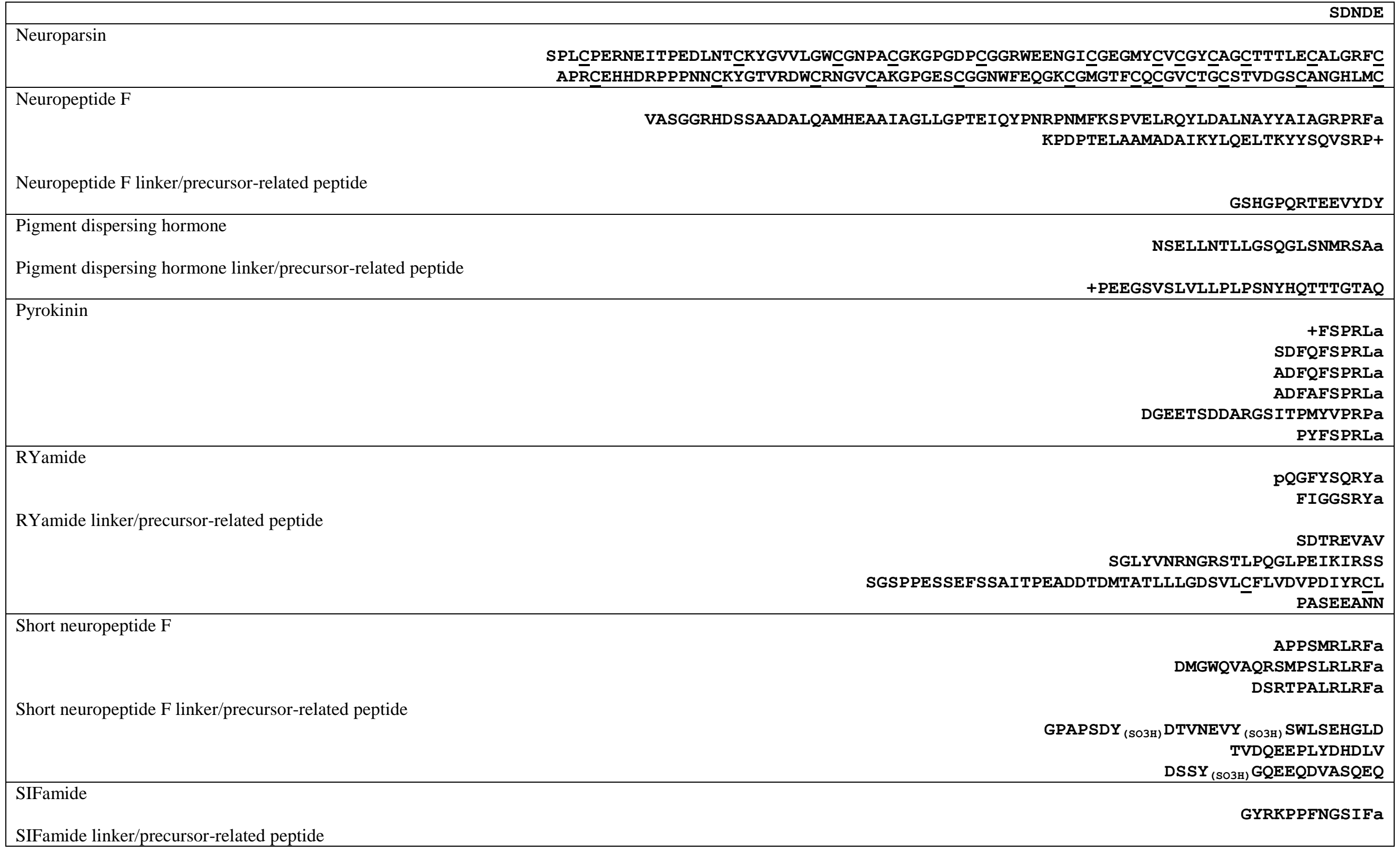




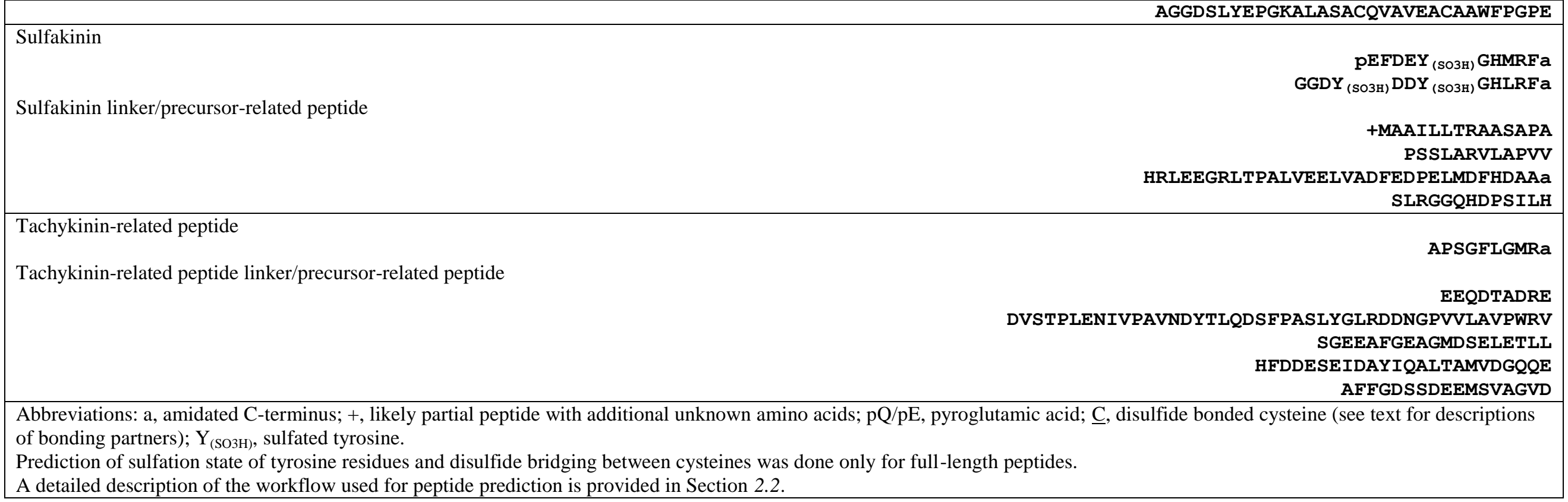




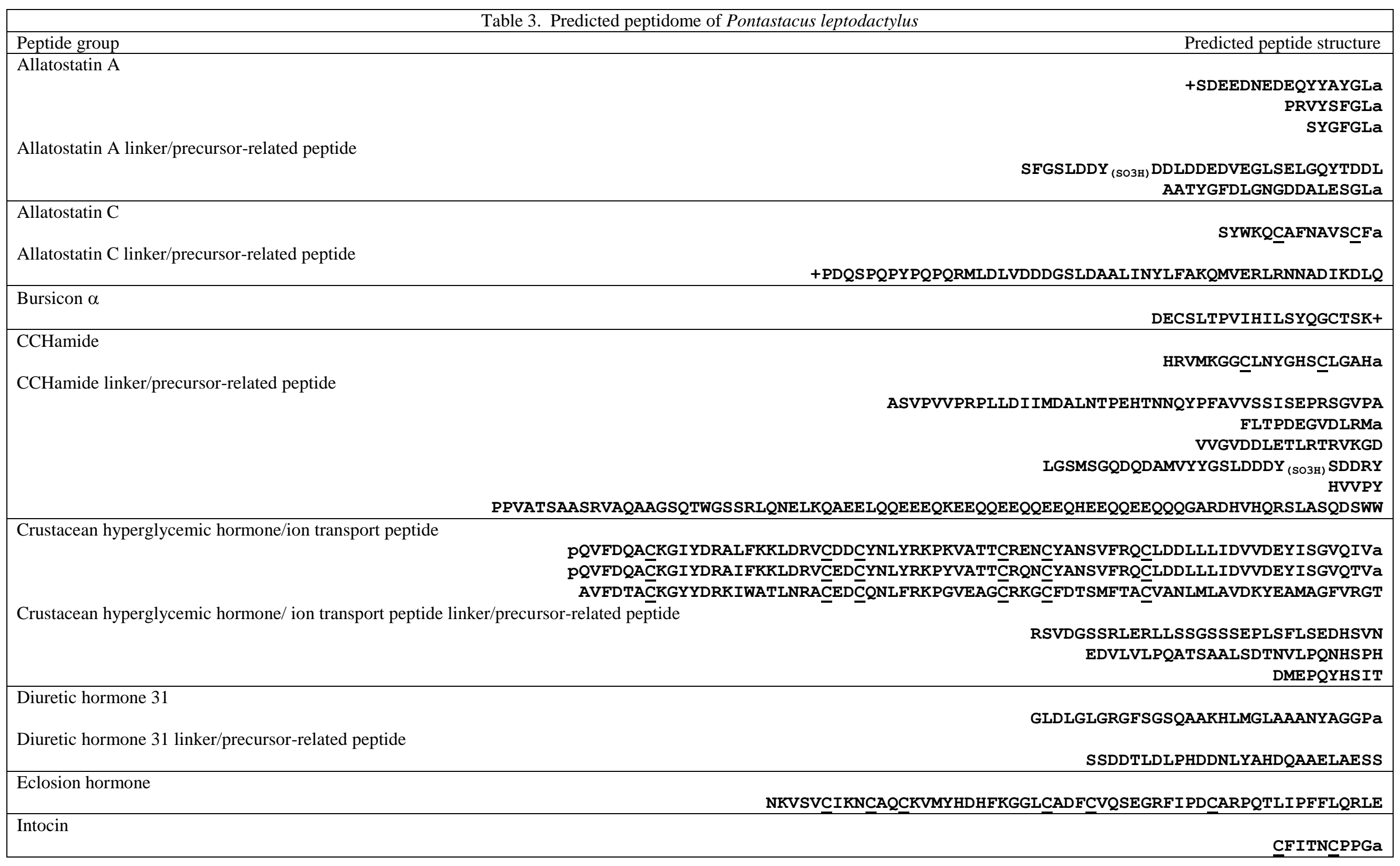




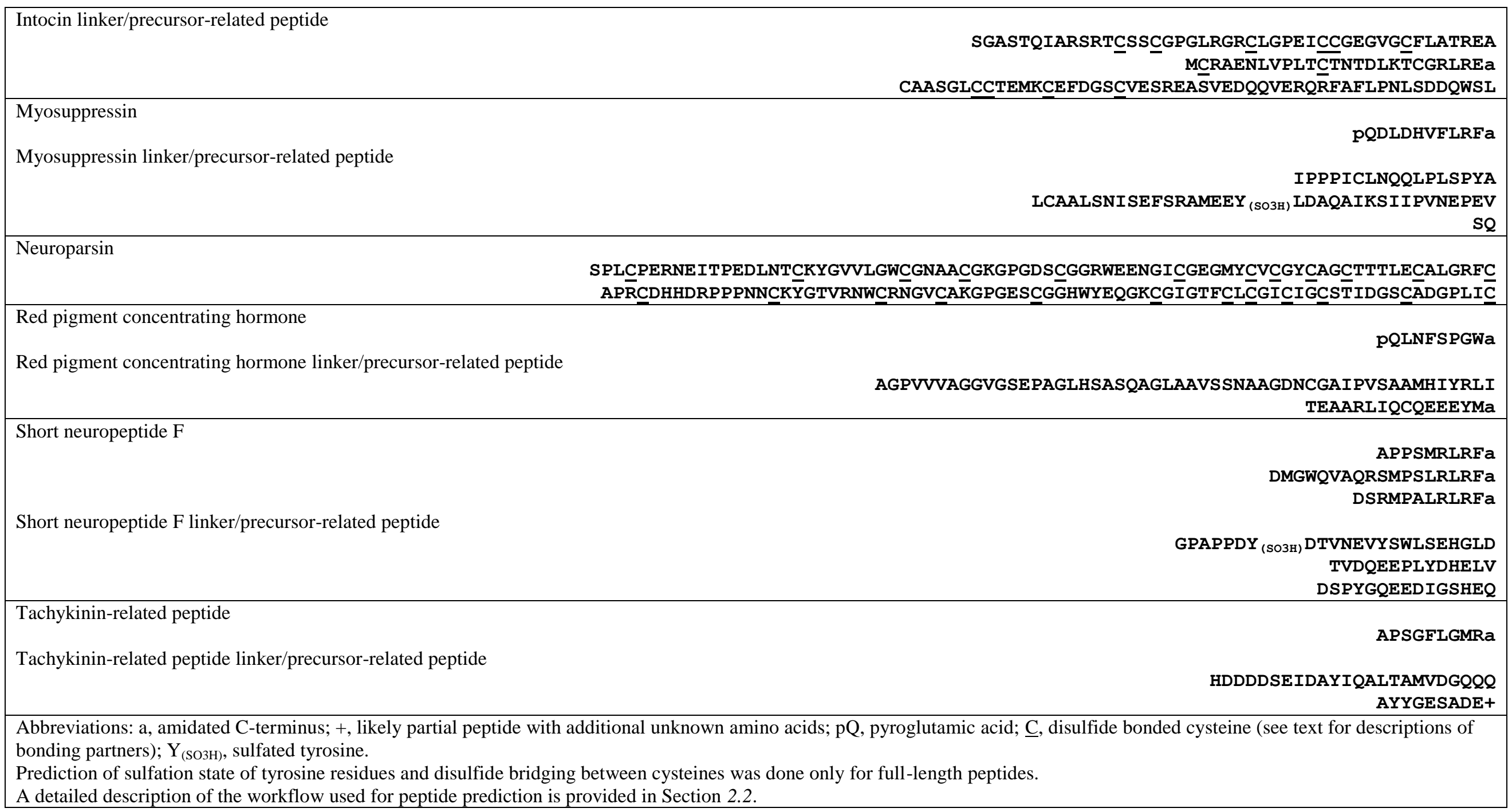




\begin{tabular}{|lc}
\hline & Table 4. Predicted peptidome of Cherax quadricarinatus \\
\hline Peptide group & Predicted peptide structure \\
\hline Bursicon $\beta$ & +THLRAREVKLTHCYDADGNRLAGERGALVITLREPSECQCLKCGDSTR \\
\hline Neuroparsin & APRCNTHDRPPPSNCKYGTVRNWCRNGVCAKAPGESCGGHWYEHGKCGIGTFCLCGVCIGCSTIDGRCADGPLMC \\
\hline $\begin{array}{l}\text { Abbreviations: +, likely partial peptide with additional unknown amino acids; } \text { C, disulfide bonded cysteine (see text for descriptions of bonding partners). } \\
\text { Prediction of disulfide bridging between cysteines was done only for full-length peptides. } \\
\text { A detailed description of the workflow used for peptide prediction is provided in Section 2.2. }\end{array}$ \\
\hline
\end{tabular}


A. Procl-prepro-adipokinetic hormone-corazonin-like peptide (from GBEV01011002) MVAWQMMLALVCLAIVPTMAQITFSRSWVPQGKRSGPLVSPAGAPSLDVDPCRDTRLSTLTDVASHLVELMDDVSDLTQDDAALALRLKHALLARQR RLT

$\downarrow$ Signal peptidase (cleavage locus highlighted above)

QITFSRSWVPQGKRSGPLVSPAGAPSLDVDPCRDTRLSTLTDVASHLVELMDDVSDLTQDDAALALRLKHALLARQRRLT

$\downarrow$ Prohormone convertase (cleavage loci highlighted above)

QITFSRSWVPQGKR SGPLVSPAGAPSLDVDPCRDTR LSTLTDVASHLVELMDDVSDLTQDDAALALRLKHALLARQRR LT

$\downarrow$ Carboxypeptidase (cleavage loci highlighted above)

QITFSRSWVPQG SGPLVSPAGAPSLDVDPCRDT LSTLTDVASHLVELMDDVSDLTQDDAALALRLKHALLARQ

$\downarrow$ Peptidylglycine- $\alpha$-amidating monooxygenase (amidation locus highlighted above)

QITFSRSWVPQamide

$\downarrow$ Glutaminyl cyclase (cyclization locus highlighted above)

PQITFSRSWVPQamide

\section{B. Procl-prepro-CCHamide I (from GBEV01004199)} MVRGVPSVIVVVGLALLTSQAWGSCSQFGHSCFGAHGKRDGGEQYPRQQEPSPLYPEVNPLAEFETRQDLPIDEVPAVTNREIVANVRNWLAVLSR RLRQKTSSQASPSAQSIGYFK

$\downarrow$ Signal peptidase (cleavage locus highlighted above) SCSQFGHSCFGAHGKRDGGEQYPRQQEPSPLYPEVNPLAEFETRQDLPIDEVPAVTNREIVANVRNWLAVLSRRLRQKTSSQASPSAQSIGYFK

$\downarrow$ Prohormone convertase (cleavage loci highlighted above) SCSQFGHSCFGAHGKR DGGEQYPRQQEPSPLYPEVNPLAEFETRQDLPIDEVPAVTNREIVANVR NWLAVLSRR LRQKTSSQASPSAQSIGYFK $\downarrow$ Carboxypeptidase (cleavage loci highlighted above) SCSQFGHSCFGAHG DGGEQYPRQQEPSPLYPEVNPLAEFETRQDLPIDEVPAVTNREIVANV NWLAVLS LRQKTSSQASPSAQSIGYF

$\downarrow$ Peptidylglycine- $\alpha$-amidating monooxygenase (amidation locus highlighted above) SCSQFGHSCFGAHamide

$\downarrow$ Enzymatic disulfide bond formation (bridged cysteines highlighted above)

SCSQFGHSCFGAHamide

C. Procl-prepro-sulfakinin (C-terminal partial protein from GBEV01027368) +MAAILLTRAASAPARPSSLARVLAPVVRHRLEEGRLTPALVEELVADFEDPELMDFHDAAGKREFDEYGHMRFGKRGGDYDDYGHLRFGRSLRGGQ HDPSILH

$\downarrow$ Prohormone convertase (cleavage loci highlighted above)

+MAAILLTRAASAPAR PSSLARVLAPVVR HRLEEGRLTPALVEELVADFEDPELMDFHDAAGKR EFDEYGHMRFGKR GGDYDDYGHLRFGR SLRGGQHDPSILH

$\downarrow$ Carboxypeptidase (cleavage loci highlighted above)

+MAAILLTRAASAPA PSSLARVLAPVV HRLEEGRLTPALVEELVADFEDPELMDFHDAAG EFDEYGHMRFG GGDYDDYGHLRFG

$\downarrow$ Peptidylglycine- $\alpha$-amidating monooxygenase (amidation loci highlighted above)

HRLEEGRLTPALVEELVADFEDPELMDFHDAAamide EFDEYGHMRFamide GGDYDDYGHLRFamide

$\downarrow$ Tyrosylprotein sulfotransferase (tyrosine targets highlighted above)

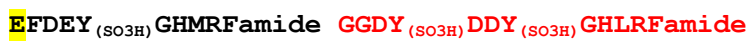

$\downarrow$ Glutaminyl cyclase (cyclization locus highlighted above)

PEFDEY (Аозн) GHMRFamide 
A. Procl-prepro-allatostatin A (from GBEV01001712)

MLGRHGAGAASLLLLLSVTATVAAYDYYLDDQDDASRLLQVLQAAATDPSYVDDYGNHQNNYGFGLGKRTPNYAFGLGKRQGMYSFGLGKRPDMYSF GLGKRPDLYSFGLGKKADMYSFGLGKRADLYSFGLGKKSGNYNFGLGKRSVSEALSSQDVSKADDLSPT IRKKRDTSPSEDIQDDKTSKHYGVGVEK REIDEDKRSRQYSFGLGKREDDDAEKRSGQYSFGLGKREPDMDLYKRPRNYAFGLGKRTSDEEDDEDDQYYPYGLGKRPRVYGFGLGKRSDDGLDDY DDLDDEEVEGLSELEQYGEDLKRADSYGLAFGNGGDALEMGLGRRSYDFGLGKRTAGPYAFGLGKRAGPYAFGLGKRSGPYAFGLGKRSGPYAFGLG KRSGPYAFGLGKRTGPYAFGLGKKADPYAFGLGKRPNPYAFGLGKRDGMYSFGLGKKAGQYSFGLGKRSGPYSFGLGKREDYDSSDQYSLGRRSGAY SFGLGKRAGPYSFGLGKRESGDESHQDEIQGSVEETSS

B. Procl-prepro-allatostatin B (N-terminal partial protein from GBEV01040422)

MQHLRAAWTLVALMVVTVVQLAASQDQQASTPGQSDAKRVGWSSMHGTWGKRPDLDDTQLEALEDKRTNWNKFHGSWGKRGEEIQAAEDKRT+

C. Procl-prepro-allatostatin C (from GBEV01001327)

MMACRSVDCHSRHQAIMLFRGTPTVATAAPSHTAAALPLLVSLMLVASAAARLPQALPRPQYMEVVRPVLPNVALEQQGTLQGAPLQISETVTTPRK RAAIVLDKLMFALQKALDDTPASPSSGAPASYPRTRTYAAGPMDLQRRGNGDGRLYWRCYFNAVSCF

D. Procl-pre-bursicon $\alpha$ (from GBEV01070554)

MGRISWVLVVMGMASMGVVSGDECSLTPVIHILSYQGCTSKPIPSFACQGRCTSYVQVSGSKLWQTERSCMCCQESGEREASVILNCPNARKGEPKQ KKILTRAPIDCMCRPCTDVEEGTVLAQEIANF I HDS PMGNVPFLK

E. Procl-pre-bursicon $\beta$ (C-terminal partial protein from GBEV01054566)

+VVRTCEEDLAVNKCEGECISKVQPSVNTPSGFLKDCRCCRETHLRARDVTLTHCYDADGNRLTGERGSLSIKLREPADCQCFKCGDSTR

F. Procl-prepro-CCHamide II (C-terminal partial protein from GBEV01015793)

+GGCLNYGHSCLGAHGKRASMPALPRPLIDIIMDALNTPEHINNMYPYAVINSLSDQRSGVPARRFLSPAGNQLGDEGVDLRLGGVVGDDDLEGVAT RVKGDSLGSTGSQDQDAMLYYGS IDDDYSDARYKRQVFSYKS PVVATSAASRVFHSTDSQDWKRIHLQKEQKQQEEQQQQENQHEEQQGTREYVPQR TLASQANWWRR

G1. Procl-prepro-crustacean hyperglycemic hormone I (internal protein fragment from GAZR01016298) +ASLGSSGVHGRSVEGSSRLEQLLSSGSSSSEPLSFLSQDHSVNKRQVFDQACKGIYDRAIFRKLELVCDDCYNLYRKPKVATTCR+

G2. Procl-prepro-crustacean hyperglycemic hormone II (from GAZR01016298)

MSQSMVWSSVMVVVVVVISSCYGRSLSSEDLQVLPQTTSPALSHASDLPEDHGPLSTPLYHSIRKRAVFDPECKGYYDRKIWAKLNLACEDCQNLFR KPGVETECRKGCFKSSMFTSCVSDLFLPVDKYQALAAFVRGT

G3. Procl-prepro-crustacean hyperglycemic hormone III (from GAZR01016298)

MLLIQASTARSSCVWFLIILGLLSQSQNTSGSFYKIRPGTLKEFEYVNCQGTFDKKL YNELNRICEDCQNIYRRDSQLAMKCKDNCFKNSWFEECVN SLLLNDQMENYNKKISYINGQDL

H. Procl-prepro-diuretic hormone 31 (from GBEV01003269)

MSLMNSTGAVLVCLVVSLVLISAVVSASLNREARAVVEIDDPDYVLELLTRLGHSI IRANELEKFVRSSGSAKRGLDLGLGRGYSGSQAAKHLMGLA AANFAGGPGRRRRSSDDALDHDDNLYAHDQVAELAESSR

I. Procl-pre-eclosion hormone (from GBEV01101142)

MIGSRKVVVSALIVLSVTLEALPLAAAAANKVSVCIKNCAQCKVMYHDHFKGGLCADFCVQSEGRFIPDCARPQTLIPFFLQRLE

J1. Procl-prepro-FMRFamide-like peptide I (from GBEV01020536 and GBEV01106719)

MPLAAWVLLATFTWCSYAHAAHAAPVP PVAAALSSPSQGFGSNNSEDDSVAQPEKRLLKYFLPGSQAWMDDGGDLYPISQEGSKRAYSDRNYLRFGR NDDDKRSRNFLRFGRSDLGDYDNRDEGGLSDSLDKRSRNFLRFGRDHSRNFLRFGRSDMEDLSLAGGPMDFPAGLLDEVDQEDLPFQEKRSPHKSYR HLVKGNRNFPRFGRGDRNFLRFGRSVDSQLNALSCDGCDGPKTSVSSTPSPTPVQPVTSTKKDISTHS IEASNPSGSTSQRMKRAVDPTFYDYGSML SYSPSSWARGFQPEEEI ITVSSED PQDVNKRAHDRNFLRFGRDRNFLRFGKRDRSNEYPPSSPSESSESLVAVSPAEYSRNVRAPQRNFLRFG

J2. Procl-prepro-FMRFamide-like peptide II (C-terminal partial protein from GBEV01105142) +KRAYSDRNFLRFGRSDVEKRNRNFLRFGRSDLGDYHNSDDETLNDSLVKRSRNFLRFGRPDMEDMFVAGGPMEFLNSLEGEVVKDDLPLEKQAAYR HRRSRNFLRFGRSVTRQLNAQSCDGCDGPKTQETTPHPPLPLRSSQRPLPSMTSLTRSSPQNPGRALLIA

J3. Procl-prepro-FMRFamide-like peptide III (C-terminal partial protein from GBEV01189645)

+AALSPPSHDFSFINNREESEGLPEKGVLKYFNPGRQGWVDGAEDYHPFAEDVSRRGFSDKNFMRFGRGGHNVLRFGRSLDTRSNTLCLVGCDEEPK TQDHTCLPTSFHPTTRVERDIQSPEPGQQTSQRKKRAASKTFYDFRKTPSYSPSSWARGFQP

K. Procl-prepro-GSEFLamide (from C-terminal partial protein from GBEV01013249) +KRAVGSEFLGKRAKASEFERKRAMGSEFLGKRAMGSEFLGKRAMGSEFLGKRAMGSEFLGKRAMGAEFLGKRATGLEFLNERVMGSELLGKRAMGS EFLGKRYMGSEFSGKRHYEPAFMHALIYDPKRAVGSEFLG

L. Procl-prepro-intocin (N-terminal partial protein from GBEV01109169)

MQVGVVMIVAAVVVGNAAACFITNCP FGKRSGASTQIARSRTCSSCGPGLRGRCLGPEICCGEEVGCFLATREARM+ 
M1. Procl-prepro-leucokinin I (N-terminal partial protein from GBEV01013648 and GBEV01006537) MVVGGRWVVVWAWLVVASVD PVTPQGTDVSPLALPGGQPSPPCLPYRLPTHPLIRCELSKRQPFYHWGGKRSPHKFGLGLPINLREVYLALFQNARS QPLRLQATEGELKRATFNPWGGKQSDPIHTASLTSDAFNDS PSKGNTFTPWGGKRSAEYYLEDESPLAVKEDIIPYVTTFSDEGQTEEIKEGSTATW GGNRVPSVSDGKNDILTEEEPSDFFLLNENLPFPDVGNLRYKREVESYVKSLENIKSSLEEKKAESGKSTQKDDQSQESNTSEVKRARYSAWVGKRP DLQAIQDAVRRLKYQEPQMAERRGFSAWAGKRSLSTVFSNIMSKKAFSAWAGKRSNYDFEQNILKKTKVSPWAEKLLDKADSTTNVATVESSPFNDQ ERASFNEWI GNAEKRQAFNAWAGKRSDTEEKRQAFSAWAGKRNDNDEKRHSFSAWAGKRREDDEKRHTFSSWAGKRSNNDEKRQAFS PWAGKRSDNE EKRQAFSSWAGKRSENDE+

M2. Procl-prepro-leucokinin II (internal protein fragment from GBEV01006538)

+DFEQNILKTKVSPWAEKLSDKADSTTNVATVESSPFNDQERASFNEWIGNAKKRQAFNAWAGKRSDTEEKRRQAFSAWAGKRSDNDEKRHSFSAWAG KRREDDEKRHAFSSWAGKRSNNDEKRQAFSPWAGKRSDNEEKRQAFSSWAGKRSENDE+

N1. Procl-pre-neuroparsin I (C-terminal partial protein from GBEV01003881)

+SCLLTLCS ILLLILQNAAASPLCPERNEITPEDLNTCKYGVVLGWCGNPACGKGPGDPCGGRWEENGICGEGMYCVCGYCAGCTTTLECALGRFC

N2. Procl-pre-neuroparsin II (from GBEV01000414)

MRTLTSFMTFVVAFYCLVLIFQEAAAAPRCEHHDRPPPNNCKYGTVRDWCRNGVCAKGPGESCGGNWFEQGKCGMGTFCQCGVCTGCSTVDGSCANG HLMC

O1. Procl-prepro-neuropeptide F I (from GBEV01005906)

MQGMVMVGTVVAAVVATLVSGVASGGRHDSSAADALQAMHEAAIAGLLGPTEIQYPNRPNMFKSPVELRQYLDALNAYYAIAGRPRFGKRGSHGPQR TEEVYDY

O2. Procl-prepro-neuropeptide F II (N-terminal partial protein from GBEV01020719)

MYRHIVSAMVVAAVVVGVLEMGAVEGKPDPTELAAMADAIKYLQELTKYYSQVSRP+

P. Procl-prepro-pigment dispersing hormone (C-terminal partial protein from GBEV01236728)

+PEEGSVSLVLLPLPSNYHQTTTGTAQKRNSELLNTLLGSQGLSNMRSAGRR

Q. Procl-prepro-pyrokinin (C-terminal partial protein from GBEV01049409)

+FSPRLGKKSDFQFSPRLGKKADFQFS PRLGKKADFAFSPRLGKRDGEETSDDARGSITPMYVPRPGRPYFSPRLG

R. Procl-prepro-RYamide (from GBEV01010112)

MTRGACPTLVLIAALITLAASQGFYSQRYGKRSDTREVAVRSGLYVNRNGRSTLPQGLPEIKIRSSRFIGGSRYGKRSGSPPESSEFSSAITPEADD TDMTATLLLGDSVLCFLVDVPDIYRCLKKPASEEANN

S. Procl-prepro-short neuropeptide F (from GBEV01004780)

MGVSAVKCWVTLLCCCVLLSQLTSAGPAPSDYDTVNEVYSWLSEHGLDRRAPPSMRLRFGKRDMGWQVAQRSMPSLRLRFGKRTVDQEEPLYDHDLV RKDSRTPALRLRFGKRDSSYGQEEQDVASQEQ

T. Procl-prepro-SIFamide (from GBEV01000221)

MCVQTRMLVAVAVVLVVLAVLSDPVSAGYRKPPFNGSIFGKRAGGDSLYEPGKALASACQVAVEACAAWFPGPEKK

U. Procl-prepro-tachykinin-related peptide (from GBEV01001769)

MVRGAAIGLMVMVVVTGALAEEQDTADRERRAPSGFLGMRGKKDVSTPLENIVPAVNDYTLQDSFPASLYYGLRDDNGPVVLAVPWRVKKAPSGFLGM RGKKSGEEAFGEAGMDSELETLLKRAPSGFLGMRGKKAPSGFLGMRGKKAPSGFLGMRGKKHFDDESEIDAYIQALTAMVDGQQEKRAPSGFLGMRG KKAFFGDSSDEEMSVAGVDKRAPSGFLGMRG 
A. Alignment of BAE45266 and Procl-prepro-allatostatin A BAE 45266 Procl-prepro-AST-A MLGRHGAGAASLLLLLSVTATVAAYDYYLDDQDDASRLLQVLQAAATDPSYVDDYGNHQN MLGRHGAGAASLLLLLSVTATVAAYDYYLDDQDDASRLLQVLQAAATDPSYVDDYGNHQN

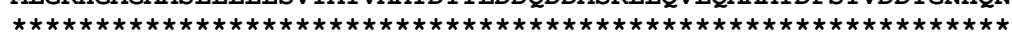

BAE 45266

Procl-prepro-AST-A

BAE 45266

Procl-prepro-AST-A

BAE 45266

Procl-prepro-AST-A

BAE 45266

Procl-prepro-AST-A

BAE 45266

Procl-prepro-AST-A

BAE 45266

Procl-prepro-AST-A

NYGFGLGKRTPNYAFGLGKRQGMYSFGLGKRPDMYSFGLGKRPDLYSFGLGKKADMYSFG NYGFGLGKRTPNYAFGLGKRQGMYSFGLGKRPDMYSFGLGKRPDLYSFGLGKKADMYSFG

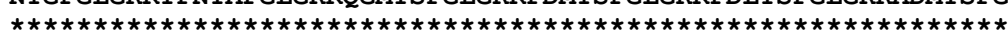

LGKRADLYSFGLGKKSGNYNFGLGKRSVSEALSSQDVSKADDLSPTIRKKRDTSPSEDIQ LGKRADIYSFGLGKKSGNYNFGLGKRSVSEALSSQDVSKADDLSPTIRKKRDTSPSEDIQ

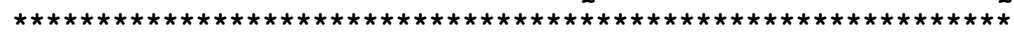

DDKTSKHYGVGVEKREIDEDKRSRQYSFGLGKREDDDAEKRSGQYSFGLGKREPDMDLYK DDKTSKHYGVGVEKREIDEDKRSRQYSFGLGKREDDDAEKRSGQYSFGLGKREPDMDLYK

RPRNYAFGLGKRTSDEEDDEDDQYYPYGLGKRPRVYGFGLGKRSDDGLDDYDDLDDEEVE RPRNYAFGLGKRTSDEEDDEDDQYYPYGLGKRPRVYGFGLGKRSDDGLDDYDDLDDEEVE

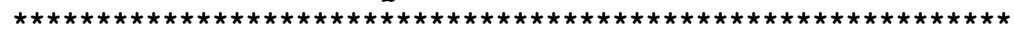

GLSELEEYGEDLKRADSYGLAFGNGGDALEMGLGRRSYDFGLGKRTAGPYAFGLGKRAGP GLSELEQYGEDLKRADSYGLAFGNGGDALEMGLGRRSYDFGLGKRT---- - - - - - - - -

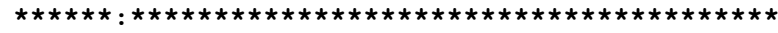

YAFGLGKRAGPYAFGLGKRAGPYAFGLGKRAGPYAFGLGKRSGPYAFGLGKRSGPYAFGL -------------AGPYAFGLGKRAGPYAFGLGKRSGPYAFGLGKRSGPYAFGL

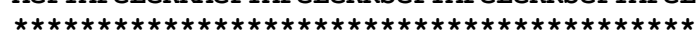

BAE 45266

Procl-prepro-AST-A

GKRSGPYAFGLGKRTGPYAFGLGKKADPYAFGLGKRPNPYAFGLGKRDGMYSFGLGKKAG GKRSGPYAFGLGKRTGPYAFGLGKKADPYAFGLGKRPNPYAFGLGKRDGMYSFGLGKKAG

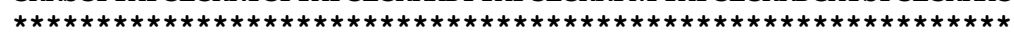

BAE 45266

Procl-prepro-AST-A

QYSFGLGKRSGPYSFGLGKREDYDSSDQYSLGRRSGAYSFGLGKRAGPYSFGLGKRESGD QYSFGLGKRSGPYSFGLGKREDYDSSDQYSLGRRSGAYSFGLGKRAGPYSFGLGKRESGD

BAE 45266

Procl-prepro-AST-A

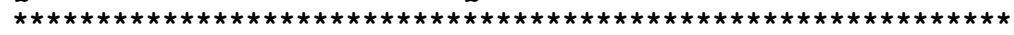

ESHQDEIQGSVEETSS

ESHQDEIQGSVEETSS

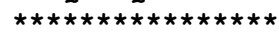

B1. Alignment of BAE06262 and Procl-prepro-FMRFamide-like peptide I

BAE06262

MTKSCVMPLAAWVLLATFTWCSYAHAAHAASVPPVVAALSSPSQGFGSNNSEDDSVAQPE

Procl-prepro-FLP-I

-----MPLAAWVLLATFTWCSYAHAAHAAPVPPVAAALSSPSQGFGSNNSEDDSVAQPE

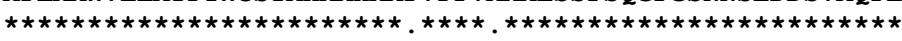

BAE06262

Procl-prepro-FLP-I

KRLLKYFHPGSQAWMDDGGDLYPISQEGSKRAYSDRNFLRFGRSDVDKRNRNFLRFGRSD KRLLKYFLPGSQAWMDDGGDLYPISQEGSKRAYSDRNYLRFGRNDDDKRSRNFLRFGRSD

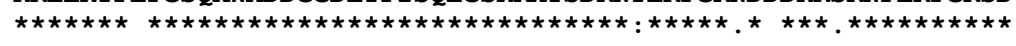

BAE 06262

LGDYDNSDDETLNDSHVKRS--------------------------------Procl-prepro-FLP-I

LGDYDNRDEGGLSDSLDKRSRNFLRFGRDHSRNFLRFGRSDMEDLSLAGGPMDFPAGLLD

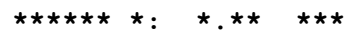

BAE06262

Procl-prepro-FLP-I

-----------------------------RNFLRFGRSVNRQLNARSCDGCDE EVDQEDLPFQEKRSPHKSYRHLVKGNRNFPRFGRGDRNFLRFGRSVDSQLNALSCDGCDG

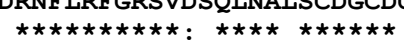

BAE06262

Procl-prepro-FLP-I

HNYPGTNPI PPPIPVQSMVPAKQDIA-HTIESPELDDSTSHRMKRAAI PTANDYGSMSSY PK-TSVSSTPSPTPVQPVTSTKKDISTHSIEASNPSGSTSQRMKRAVDPTFYDYGSMLSY

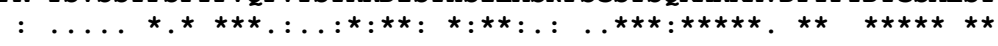

BAE06262

Procl-prepro-FLP-I

BAE06262

Procl-prepro-FLP-I

SPIAWARGFQPEEQI ITVSSEDPQDVNKRALDRNFLRFGRDRNFLRFGRNRNFLRFGKRD

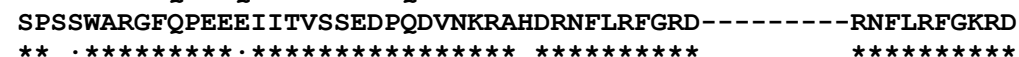

RSNEYRPSSPSESSESLVAVSPAEYSRNVRAPQRNFLRFG

RSNEYPPSSPSESSESLVAVSPAEYSRNVRAPQRNFLRFG

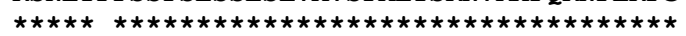

B2. Alignment of BAE06263 and Procl-prepro-FMRFamide-like peptide I

BAE06263

Procl-prepro-FLP-I

MTRSCVMPLAAWVLLATFSWCSYAHAAHAAPVPPVAAALSSPSQGFGSNNSEDDSVAQPE ----- MPLAAWVLLATFTWCSYAHAAHAAPVPPVAAALSSPSQGFGSNNSEDDSVAQPE

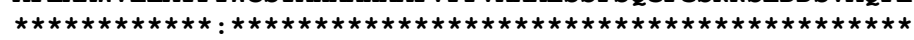

BAE06263

Procl-prepro-FLP-I

KRLLKYFHPESQAWMDDGGDLYPISQEGSKRAYSDRNYLRFGRSDVDKRNRNFLRFGRSD KRLLKYFLPGSQAWMDDGGDLYPISQEGSKRAYSDRNYLRFGRNDDDKRSRNFLRFGRSD

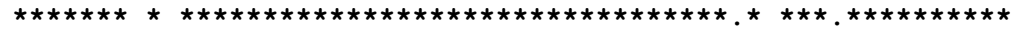




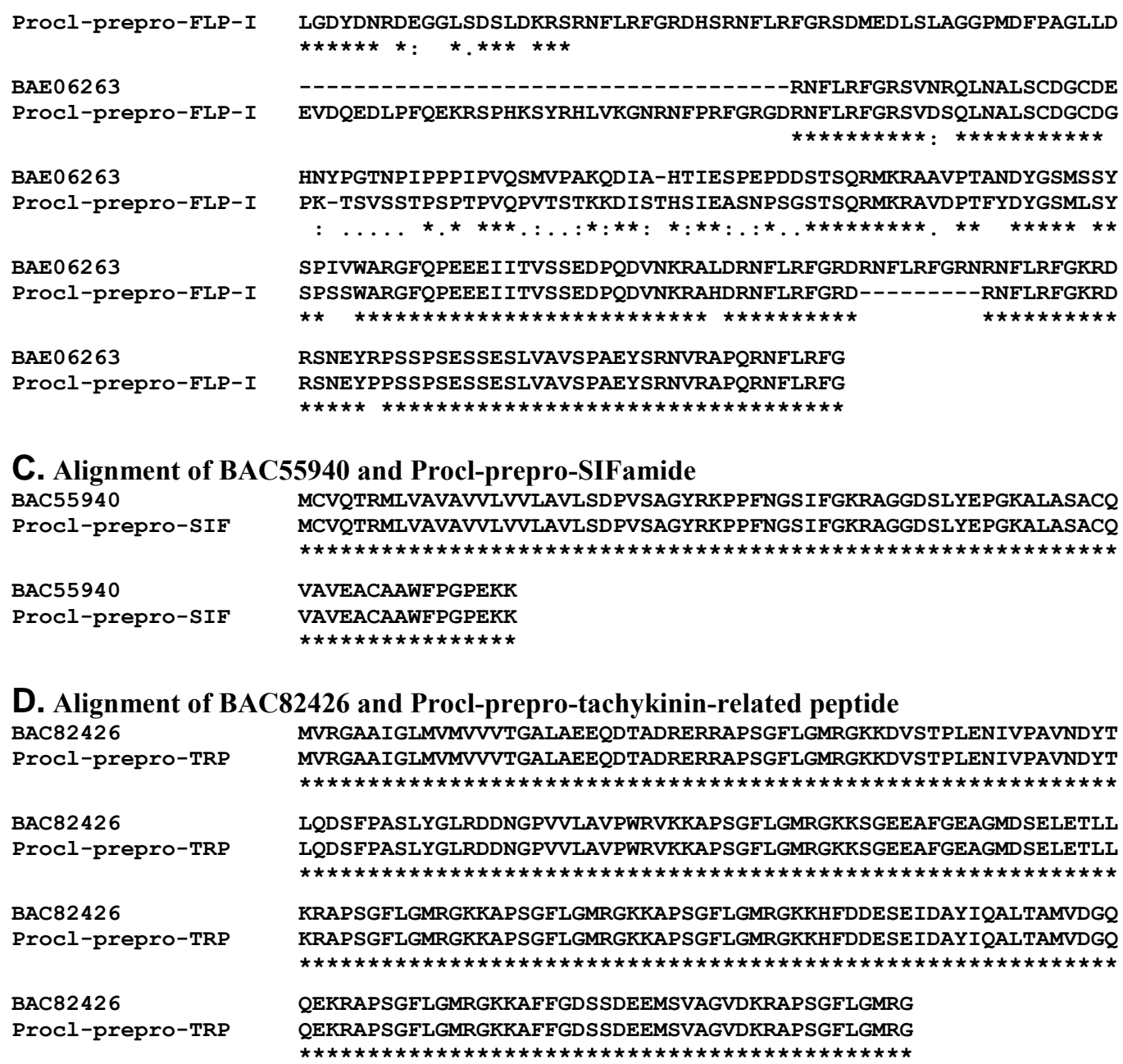

C. Alignment of BAC55940 and Procl-prepro-SIFamide

BAC55940

MCVQTRMLVAVAVVLVVLAVLSDPVSAGYRKPPFNGSIFGKRAGGDSLYEPGKALASACQ

Procl-prepro-SIF MCVQTRMLVAVAVVLVVLAVLSDPVSAGYRKPPFNGSIFGKRAGGDSLYEPGKALASACQ

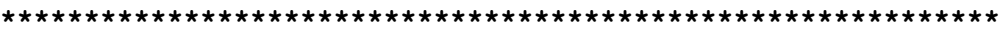

BAC55940

VAVEACAAWFPGPEKK

Procl-prepro-SIF VAVEACAAWFPGPEKK

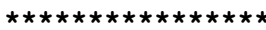

D. Alignment of BAC82426 and Procl-prepro-tachykinin-related peptide

BAC82426

Procl-prepro-TRP

BAC 82426

Procl-prepro-TRP

BAC82426

Procl-prepro-TRP

BAC82426

Procl-prepro-TRP

MVRGAAIGLMVMVVVTGALAEEQDTADRERRAPSGFLGMRGKKDVSTPLENIVPAVNDYT MVRGAAIGLMVMVVVTGALAEEQDTADRERRAPSGFLGMRGKKDVSTPLENIVPAVNDYT

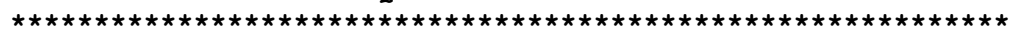

LQDSFPASLYGLRDDNGPVVLAVPWRVKKAPSGFLGMRGKKSGEEAFGEAGMDSELETLL LQDSFPASLYGLRDDNGPVVLAVPWRVKKAPSGFLGMRGKKSGEEAFGEAGMDSELETLI

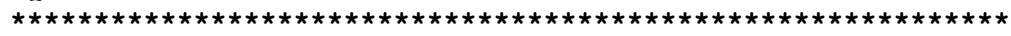

KRAPSGFLGMRGKKAPSGFLGMRGKKAPSGFLGMRGKKHFDDESEIDAYIQALTAMVDGQ KRAPSGFLGMRGKKAPSGFLGMRGKKAPSGFLGMRGKKHFDDESEIDAYIQALTAMVDGQ

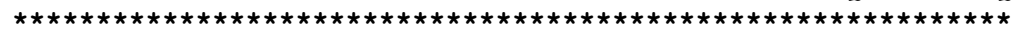

QEKRAPSGFLGMRGKKAFFGDSSDEEMSVAGVDKRAPSGFLGMRG QEKRAPSGFLGMRGKKAFFGDSSDEEMSVAGVDKRAPSGFLGMRG

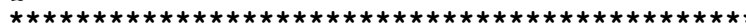


A. Ponle-prepro-allatostatin A (internal protein fragment from GAFS01069035) +SDEEDNEDEQYYAYGLGKRPRVYSFGLGKRSFGSLDDYDDLDDEDVEGLSELGQYTDDLKRAATYGFDLGNGDDALESGLGRRSYGFGLGKRS+

B. Ponle-prepro-allatostatin C (C-terminal partial protein from GAFY01028258) +PDQSPQPYPQPQRMLDLVDDDGSLDAALINYLFAKQMVERLRNNADIKDLQRKRSYWKQCAFNAVSCFGKRK

C. Ponle-pre-bursicon $\alpha$ (N-terminal partial protein from GAFY01028258)

MGRISWVLVMMGMASVGVVLDECSLTPVIHILSYQGCTSK+

D. Ponle-prepro-CCHamide (from GAFS01018472)

MPVPRSSAILLIAFPLVLLWAPPITGHRVMKGGCLNYGHSCLGAHGKRASVPVVPRPLIDIIMDALNTPEHTNNQYPFAVVSSISEPRSGVPARRFL TPDEGVDLRMGRVVGVDDLETLRTRVKGDRLGSMSGQDQDAMVYYGSLDDDYSDDRYKRHVVPYKRPPVATSAASRVAQAAGSQTWGSSRLQNELKQ AEELQQEEEQKEEQQEEQQEEQHEEQQEEQQQGARDHVHQRSLASQDSWWRR

E1. Ponle-prepro-crustacean hyperglycemic hormone I (from GAFS01024727) MVACRRMWSLVVVVVVVVVVSLGPSGVRGRSVDGSSRLERLISSGSSSEPLSFLSEDHSVNKRQVFDQACKGIYDRALFKKLDRVCDDCYNLYRKPK VATTCRENCYANSVFRQCLDDLLLIDVVDEYISGVQIVGK

E2. Ponle-prepro-crustacean hyperglycemic hormone II (internal protein fragment from GAFS01049968) +NKRQVFDQACKGIYDRAIFKKLDRVCEDCYNLYRKPYVATTCRQNCYANSVFRQCLDDLIIIDVVDEYISGVQTVG+

E3. Ponle-prepro-crustacean hyperglycemic hormone III (from GAFS01042936) MSQSMVWSSVMVVVVLTSSCTGRSLSEDVLVLPQAT SAALSDTNVLPQNHSPHRRDMEPQYHS ITKRAVFDTACKGYYDDRKIWATLNRACEDCQNLF RKPGVEAGCRKGCFDTSMFTACVANLMLAVDKYEAMAGFVRGT

F. Ponle-prepro-diuretic hormone 31 (C-terminal partial protein from GAFS01038688) +KRGLDLGLGRGFSGSQAAKHLMGLAAANYAGGPGRRRRSSDDTLDLPHDDNLYAHDQAAELAESSR

G. Ponle-pre-eclosion hormone (from GAFS01039705)

MIGSRKVVVSALLVLSVMLAALLVLPLSAAAANKVSVCIKNCAQCKVMYHDHFKGGLCADFCVQSEGRFIPDCARPQTLIPFFLQRLE

H. Ponle-prepro-intocin (from GAFS01000331)

MQVGVVMIVAAVVVGNAAACFITNCPPGGKRSGASTQIARSRTCSSCGPGLRGRCLGPEICCGEGVGCFLATREARMCRAENLVPLTCTNTDLKTCG RLREGRCAASGLCCTEMKCEFDGSCVESREASVEDQQVERQRFAFLPNLSDDQWSL

I. Ponle-prepro-myosuppressin (from GAFS01019764)

MMYGSRSWCSLLLVSVVVALGVCVGVGEAIPPPICLNQQLPLSPYAKKLCAALSNISEFSRAMEEYLDAQAIKS I IPVNEPEVKRQDLDHVFLRFGR SQ

J1. Ponle-pre-neuroparsin I (from GAFS01000216)

MRTTISCTSGVSCLIAFCSILLLLILQNATASPLCPERNEITPEDLNTCKYGVVLGWCGNAACGKGPGDSCGGRWEENGICGEGMYCVCGYCAGCTT TLECALGRFC

J2. Ponle-pre-neuroparsin II (from GAFY01019447 and GAFS01005142)

MRTLTSFITFVVAFYCLVLLFQEAAAAPRCDHHDRPPPNNCKYGTVRNWCRNGVCAKGPGESCGGHWYEQGKCGIGTFCLCGICIGCSTIDGSCADG PLIC

K. Ponle-prepro-red pigment concentrating hormone (C-terminal partial protein from GAFS01040704) +LLMVAVVVLASCVSGQLNFSPGWGKRAGPVVVAGGVGSEPAGLHSASQAGLAAVSSNAAGDNCGAIPVSAAMHIYRLIRTEAARLIQCQEEEYMG

L. Ponle-prepro-short neuropeptide F (from GAFS01014236)

MGVSVVKCWVALVCCGVLLSQLTSAGPAPPDYDTVNEVYSWLSEHGLDRRAPPSMRLRFGKRDMGWQVAQRSMPSLRLRFGKRTVDQEEPLYDHELV RKDSRMPALRLRFGKRDSPYGQEEDIGSHEQ

M. Ponle-prepro-tachykinin-related peptide (internal protein fragment from GAFS01072672)

+KKAPSGFLGMRGKKAPSGFLGMRGKKHDDDDSEIDAYIQALTAMVDGQQQKRAPSGFLGMRGKKAYYGESADE+ 
Figure 5

A. Chequ-pre-bursicon $\beta$ (C-terminal partial protein from GADE01008158) +THLRAREVKLTHCYDADGNRLAGERGALVITLREPSECQCLKCGDSTR

B. Chequ-pre-neuroparsin (from GADE01014957)

MRTLTFFISFVVTFYCLVLLFQEAAAAPRCNTHDRPPPSNCKYGTVRNWCRNGVCAKAPGESCGGHWYEHGKCGIGTFCLCGVCIGCSTIDGRCADG PLMC 
A. Structural comparison of known astacidean red pigment concentrating hormone (RPCH), adipokinetic hormone-corazonin-like peptide (ACP) and corazonin isoforms RPCH

ACP PQITF--SRSWVPQamide PQLNF--SPGW---amide

Corazonin PQ-TFQYSRGWTN-amide

\section{B. Alignment of known crustacean ACP isoforms}

Procl-ACP

Spetu-ACP

PQITFSRSWVPQ-amide

Tigca-ACP-I

PQVTFSRDWNA--amide

Tigca-ACP-II

PQITFSRDWLAGSamide

SPVTFDRDWLAGSamide

Eucse-ACP-I

PQITFSRDWLAGSamide

Eucse-ACP-II

ASPISFSRDWLAS-amide

Eucse-ACP-III

TPVTFSRDWLAS-amide

Eucse-ACP-IV

AKPISFSREWLAS-amide

C. Alignment of known crustacean ACP isoforms

Trica

Spetuf

Procl

Tigca

Eucse-I

Eucse-II

Trica

Spetuf

Procl

Tigca

Eucse-I

Eucse-II

Trica

Spetu

Procl

Tigca

Eucse-I

Eucse-II
MALKF-R-----VFALVAVLVLMAWMFTGTQAOVTFSRDWNP--GKRT----------MNQRLDRVYPAVMGSFLISLVLLSAFTQMTVAQVTESRDWNA--GKRS---------------------MVAWQMMLALVCLAIVPTMAQITFSRSWVP-QGKRSGPLVSP--.--MSKRS-TLFDVIFVCVVMSAIVLA---STVDGQITFSRDWLAGSGKRS-PVTFDRDWLAG MKNSF-------PSNLCLSLALLFFIASMADAQITFSRDWLAGSGKRASPISFSRDWLAMRTSI-------ALCIVVVVAYLACMPEQTQAQITFSRDWLAGSGKRAKPISFSREWLA:

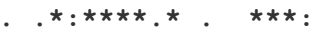

-----------ENTDLHNTLKTA----- SAVCHLLMNQVRQLASCDNNNELEP -----0----- GAAALY PDCAMP-ERALLSEVSKL IHNEAQRMVSCQ------AGAPSLD------VDPCRDTRLSTLTDVA------SHLVEL-MDDVSDLTQDDAALALRL SGKRSV--------------GSYPGKVMLPPREAIEELANYLLLQLS-----DSPMA--SGKRTPVTFSRDWLASGKRSGDNTDSWICVPKFAVAPLVHFMVEHEQKESYDFQPHA---

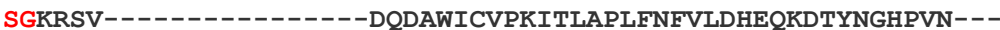

GATIFSGRR-----

AWTVLRG------

KHALLARQRR--LT

KMSFMKHLQGHSEA

STGTLHEDQ-----

QEA---------- 